\title{
Unbound by Theory and Naming: Survival Feminism and the Women of the South African Victoria Mxenge Housing and Development Association
}

\author{
Becky Jacobs \\ University of Tennessee, jacobs@utk.edu
}

Follow this and additional works at: https://trace.tennessee.edu/utk_lawpubl

Part of the Law Commons

\section{Recommended Citation}

Jacobs, Becky L., Unbound by Theory and Naming: Survival Feminism and the Women of the South African Victoria Mxenge Housing and Development Association (December 1, 2009). Berkeley Journal of Gender, Law \& Justice, Vol. 26, No. 19, 2011; University of Tennessee Legal Studies Research Paper No. 151. Available at SSRN: https://ssrn.com/abstract=1816575 or http://dx.doi.org/10.2139/ssrn.1816575

This Publication is brought to you for free and open access by the Law at TRACE: Tennessee Research and Creative Exchange. It has been accepted for inclusion in College of Law Faculty Scholarship by an authorized administrator of TRACE: Tennessee Research and Creative Exchange. For more information, please contact trace@utk.edu. 
Article

\title{
*19 UNBOUND BY THEORY AND NAMING: SURVIVAL FEMINISM AND THE WOMEN OF THE SOUTH AFRICAN VICTORIA MXENGE HOUSING AND DEVELOPMENT ASSOCIATION
}

\author{
Becky L. Jacobs [FNd1]
}

Copyright (c) 2011 Regents of the University of California; Becky L. Jacobs

\begin{abstract}
The emergence of a uniquely African formulation of feminism is one of the most energizing developments in feminist theory and discourse in recent history. As African women confront unprecedented economic and political challenges, they also are questioning, and, in some instances, redefining, individual and societal orthodoxies of gender and family roles. This Article will examine the discourse on African feminism and will consider the practical utility of feminist theory in the context of one extraordinary group of South African women, the members of the Victoria Mxenge Housing and Development Association. The discussion will review the historical context in which the Association evolved, will reflect upon a few of the impediments that its members confronted, and will contemplate the challenges and possibilities that these women continue to encounter.
\end{abstract}

Table of Contents

II. The Victoria Mxenge Housing

and Development Association

A. The Historical Context

B. The Legal Framework--Women's

Rights and The Right to Housing

C. The Association 


\section{*20 Introduction}

The emergence of a uniquely African formulation of feminism is one of the most energizing developments in feminist theory and discourse in recent history. As African women [FN1] confront unprecedented economic and political challenges, they also are questioning, and, in some instances, redefining, individual and societal orthodoxies of gender and family roles. [FN2] This Article will examine the discourse on African feminism [FN3] and will consider the practical utility of feminist theory in the context of one extraordinary group of South African women, the members of the Victoria Mxenge (pronounced / m 'k n gel/) Housing and Development Association. This group created saving schemes and engaged state mechanisms to finance the self-help construction and ownership of their own housing. Today, their collection of homes has grown into a village, complete with a community center, a childcare facility, and small shops. The struggle of these women against harsh and material oppression not only improved their own personal realities, but also paved the way for thousands of other South Africans to achieve their dreams. Their re-conceptualization of the notion of "homemaker" parallels the restructuring of South Africa's civil, political, and financial economies.

\section{African "Feminism"}

African women do feminism; feminism is what they do for themselves and for $* \mathbf{2 1}$ others.--Obioma Nnaemeka [FN4]

The struggle to locate feminist theory within the context of African women's past, present, and future realities has forced feminists from all corners of the globe to engage in a stimulating and productive examination of the horizons of feminist practice. [FN5] This locational dialogue contains analogies to the "global standards-local values" debate in human rights discourse, as well as to the evolution of the revived feminist movement globally and its autogenous deliberations. [FN6]

The transnational "north-south" discourse clearly informs African gender studies. One dominant constituent of the north-south colloquy is the critique of "northern feminism" emanating from the black diaspora. [FN7] Black diasporic feminists such as bell hooks [FN8] criticize northern-based feminism as representing the insular and essentialist perspective of white middle-class feminists from the West. [FN9] Among the predominant western feminist paradigms, American feminism tends to emphasize political and socio-historical experience, [FN10] while French feminism often deconstructs power hierarchies and the societal construction of gender. [FN11] As described by Alice Jardine, [FN12] these American feminists theorize "woman as sexual identity[,]" while the French lucubrate "woman as process." [FN13]

As intellectually generative as these perspectives may be, diasporic feminists*22 argue that the theoretical concerns reflected therein are of significantly diminished importance to women who face substantial economic difficulties. [FN14] Those who espouse these perspectives, diasporists argue, separate theory from practice, [FN15] ultimately rendering them reluctant to or incapable of confronting the material oppression of non-western women. [FN16] So framed, western theorists are viewed with skepticism or contempt by many diasporic scholars and are often dismissed as "privileged and bourgeois." [FN17] In sum, western feminists are perceived to be focused on "meanings at the expense of doings," [FN18] and their refusal to engage in activism in favor of utopian theorizing renders these theorists superfluous to women in the global south. [FN19] 
Furthermore, the western, utopian formulation of a homogenous and unified sisterhood has been criticized as not taking into account the socio-structural inequalities of women. Without addressing these differentials, the search for a formal theoretical standard of equality will necessarily be essentialistic and likely will not improve women's lives. Critics contend that most western conceptualizations of feminism are irrelevant in a broader context as they do not acknowledge the social, economic, and cultural disadvantages suffered by women in non-western societies. [FN20]

Given these critiques, it is not without reason that many noted writers and gender scholars on the African subcontinent reject feminist formulations denominated as "western." For some African women, it is about "the "West and the Rest of Us." [FN21] South African Nobel Prize winner Nadine Gordimer, for example, rejects feminism as a concern of white women. [FN22] Noted Nigerian writer Dr. Ifi Amadiume is even more dismissive, condemning white feminists for engaging in a "victim imperialism" that exploits the experiences of black women to promote their gender-based antidiscrimination agenda. [FN23]

Beyond the praxial dialogue, this feminist north-south debate introduces geography and economic development as well as race and class as important intersections impacting black women's experiences of discrimination. [FN24] According to southern-oriented feminists, American feminists--even Americans identified $* \mathbf{2 3}$ as black diaspora feminists--may "understand sexism in their class societies but fail to understand it in the more complex situation of the Third World, where class and sex oppression are joined by colonial and racial oppression." [FN25] Southern feminists rebuke northern feminists for not addressing the impact of colonialism on the lives of women in the south. [FN26]

One common theme articulated in the black diaspora/north-south feminist debates is that black women are victims of "triple oppression"--oppression that conflates gender, race, and class. [FN27] Marxist feminist theory has influenced this thematic proposition, due in part to the involvement of African American feminists who often are Marxist in orientation. Scholars with this inclination seek to demolish patriarchal social structures at their racist and socio-economic foundations in the cause of a radically reordered society. However, Marxist feminism, despite its theoretical alignment with its African counterpart, is vulnerable to the same critique that is directed at so-called western feminism, that of transformative failure. [FN28] In order to respond to the triple oppression to which African women are subjected, feminist inquiry must address "women's uneven and unequal participation in development and their exclusion from the benefits of socioeconomic, cultural, and political gains" if it seeks to be a relevant project. [FN29]

This theoretical polyphony and ambiguity in the global feminist community "mirrors the controversy-ridden feminist discourse in Africa." [FN30] Indeed, feminism is often viewed with skepticism, if not complete rejection, in Africa, even by noted gender scholars. Africans have established a cautious relationship with feminist theoretical developments worldwide, and a chorus of black voices has emerged to offer a response to western, primarily white, feminism. These voices are in effect "indigenizing" feminist theories and are reorienting them to accommodate country-, culture-, and class-specific gender issues. [FN31]

While this indigenization perplexes many western scholars, who view it as a manifestation of the reluctance of many African women to fully embrace traditional concepts of feminism, such scholars nevertheless find it difficult to comfortably counter the concomitant African critiques of western feminism, primary $\mathbf{* 2 4}$ among them a "cultural" critique and one more accurately identified as "praxial."

Consider first the "cultural" critique. The purveyors of this critique, among them Ifi Amadiume, question the suitability of transposing western critiques of patriarchy onto non-western societies. [FN32] This exposition rejects what many African women perceive to be the non-acceptance of African traditions by western feminists whose dialectic often is stereotypically understood as being based upon the fundamental rejection of marriage and motherhood. [FN33] Africans 
fear, not irrationally, that feminism could interfere in a disruptive and culturally insensitive manner with existing societal relationships, including those associated with maternal roles. [FN34]

The cultural critique identifies motherhood as vital to all black women and as the foundational ideology of many African women. [FN35] Motherhood, so often conceived by western feminists as a means of confining women within a patriarchally-constructed hierarchy, has been a primary self-description invoked by African women. This Mother Africa ideal [FN36] stands in contrast to the "'Euro-feminist view of motherhood as a condition of passivity and confinement." [FN37] The identities of many white middle-class feminists are framed by their "liberation" from the family and domesticity, and, consequently, western feminists frequently express impatience with what they perceive as the collaboration of third world women in their own oppression. [FN38]

This perception is the point of departure for the cultural critique. According to "cultural critics," not only does this impatience dramatically illustrate the insensitivity or indifference of western feminists to African socio-economic conditions, but it also reveals a rather stunning hypocrisy. The liberation so privileged by western women who enter the working world and escape the "drudgery of domesticity" often is made possible by the labor of poorly paid black or non-white women. [FN39] It is not without irony, then, that these white middle-class women engage in the "oppression" of black women whose notions of home, motherhood, and family western feminists so scorn. [FN40]

Thus, for many black and working-class women, the "freedom" to enter the formal economy is frequently oppressive. [FN41] Women who engage in income-producing work outside the household also are often burdened with long and $* 25$ physically demanding hours of childrearing and domestic work in the home. [FN42] Conversely, African women have achieved some of their greatest moments of solidarity and political "triumphs" in their roles as mothers. Women in South Africa, for example, were catalyzed to join the anti-apartheid struggle as mothers protecting their children and their homes. [FN43] South African mothers challenged the scourge of apartheid as its effects invaded too deeply into their private spheres of influence. [FN44] These "[w]omen struggling to liberate themselves from the burden of oppression by imperialism--a burden which manifests itself in extreme ways through poverty, disease, genocide--appear to find little point of comparison between their goals and the concerns of western women." [FN45]

Indigenized theoretical constructs based upon the "cultural" critique and the Mother Africa ideal must give rise to an "[ever-] expanding taxonomy of positioned interpretations of [African] women's experience," [FN46] the labeling of which has evolved into a delicately nuanced lexicon. Women have long been engaged in this lexical project, [FN47] and it now appears that, within the global feminist community, individuals can no longer self-identify as merely feminists. Instead, the term "feminist" no longer provides meaningful context unless prefaced with an adjectival modifier such as "white heterosexual," "black," "lesbian," or "material." [FN48] This taxonomic ambiguity extends into the African "indigenization" project and is one obstacle to formulating a uniquely African feminist theory. How do African feminists "name" and place themselves when many have chosen to eschew the "feminist" label altogether?

Within this hierarchy of nomenclature, the most prominent may be Alice Walker's "womanist" [FN49] vision of black feminism. Poet Walker has explained that she did not choose the term "womanism" to narrow or criticize existing terms, but rather because she disliked being forced to add a color in order to become visible, as in black feminist; in contrast, "[w]omanism gives us a word of *26 our own." [FN50] As Ms. Walker remarked in 1983, "Womanist is to feminist as purple to lavender"--womanist and womanism layer shades of race and class into the gendered prism made visible by feminism. [FN51]

Another configuration of "womanism" is Clenora Hudson-Weems' pioneering "Africana womanism" paradigm. This paradigm is a family-centered concept created for women of African descent rather than the traditional female-centered 
construct associated with women's movements in general. [FN52] According to scholar Hudson-Weems, black women by their historical and cultural realities are not feminists, and women are not feminists simply because they are concerned with gender issues. [FN53]

Chikwenye Okonjo Ogunyemi also conceived of an African "womanism" alternative to the feminist label, a conception that is quite distinct from that of Walker or Hudson-Weems. This definition of African womanism is an "inclusive, mother-centered ideology with a focus on caring--familial, communal, national, and international." [FN54] Professor Ogunyemi not only distinguishes African womanism from white feminism, she also differentiates African-American womanism from African womanism, insisting that only African women may lay claim to the latter moniker. [FN55] This concept of African womanism expands the gender focus of feminist inquiry to include "racial, cultural, national, economic, and political considerations." [FN56]

Nigerian literary critic Mary E. Modupe Kolawole also has explored the concept of "womanism" as an ideology that she defines as the "totality of feminine self-expression, self-retrieval, and self-assertion in positive cultural ways." [FN57] The delineation of a uniquely African theory of feminism is, she asserts, consistent with the role of self-naming in African societies. [FN58] Professor Kolawole's study of the history of oral and written genres by and about women confutes the archetype of "voiceless" African women. [FN59]

Other "names" have joined this branch of the taxonomic lexicon. For example, Nigerian scholar Molara OgundipeLeslie proposed another alternative concept for which she coined a completely new term, "stiwanism," the acronym for Social Transformation Including Women in Africa. [FN60] In her opinion, this $* \mathbf{2 7}$ term circumvents the divisive discourse associated with the issue of feminism in Africa and allows a more focused and realistic discussion of the needs of African women today. [FN61]

Other lexical nuances have been posited, including the "nego-feminism" of Obioma Nnaemeka, a feminism of negotiation--a "no ego" feminism that embodies the "shared values that can be used as organizing principles in discussions about Africa." [FN62] Consider too the "Motherism" theorized by Catherine Obianuju Acholonu. According to Obianuju Acholonu:

Afrocentric feminist theory [] must be anchored on the matrix of motherhood which is central to African metaphysics and has been the basis of the survival and unity of the black race through the ages. Whatever Africa's role may be in the global perspective, it could never be divorced from her quintessential position as the Mother Continent of humanity .... Africa's alternative to western feminism is MOTHERISM and Motherism denotes motherhood .... [FN63]

Many African women, however, remain skeptical of feminist theory regardless of its name and often are reluctant to name themselves in any way. As one writer has so insightfully noted, "definitions belong[] to the definers--not the defined." [FN64] Indeed, many of the concepts of African feminism developed by noted female African scholars, for example, Africana womanism or stiwanism, are reported to be relatively unknown in Africa. [FN65]

Further, while various such ideological and taxonomic nuances have emerged to respond to the "cultural" assessment, it is much more difficult to counter the second and perhaps more serious critique, to which this author refers as the "praxial." This critique posits that western feminist theories do not contemplate the material deprivations that black African women face. [FN66] Non-western feminists have seized upon this praxial criticism to "challenge ... fellow feminists to interrogate globalization and the negative impact of northern economic dominance on the lives of women in the south." [FN67]

One compelling praxial rejection of western gender pedagogy is based upon the contention that "Africa's present situ- 
ation has no place for feminist luxury." [FN68] Women have often suffered disproportionately in African crises. [FN69] African*28 women have lower educational levels, women continue to engage in agricultural and other lower-income producing rural activities, and women have higher levels of malnutrition and elevated maternal mortality rates. [FN70] Critics of western feminism complain that these theorists operate solely within the realm of intellectual abstractions of gender, and as such, they exhibit an apparent blindness to the realities of women's lives in the developing world. [FN71] Such intellectual exercises disregard the continent's poverty, political crises, racism, and class issues. [FN72] In short, no amount of theory will address the unmet needs and suffering of women in Africa.

The South African Nobel Prize-winning writer Nadine Gordimer declares feminist concerns to be irrelevant to the real problems of her country, and this sentiment is shared by many throughout the continent. [FN73] As Chikwenye Okonjo Ogunyemi aptly noted, "What after all, is the value of sexual equality in a ghetto?" [FN74] Africans view gender relationships only in the context of other conjunctions--not only political, cultural, and social, but also economic. [FN75]

Yet these privilege-defined differences are not confined behind "north-south" or "western-non-western" debate lines. Tension also exists within the African "sisterhood." One finds it among women in South Africa, where it has given rise to hostilities within the local feminist community. [FN76] During South Africa's apartheid era, a political victory for white women often was not perceived as a "feminist" victory. [FN77] While there still is a reluctance to frame public debate in terms of race, including within the academic and largely intellectual debate among feminist scholars in South Africa, black feminists have complained that they have been "marginalized, objectified and degraded" by elitist feminist practitioners who are vested in the academic niches from which they purport to speak for their unenlightened sisters of color. [FN78] In part based upon socio-economic experiential disparities, some African gender scholars accuse their more privileged colleagues of being just as alienated from the concerns of grassroots women as "northern" women. [FN79]

Several theoretical "development" approaches have arisen that somewhat respond to the praxial critique, including Women in Development ("WID"), *29 Woman and Development ("WAD"), and Gender and Development ("GAD"). [FN80] The etymology of these related, but distinct, frameworks is Danish economist Ester Boserup's groundbreaking work, Woman's Role in Economic Development. [FN81] Her analysis concluded that development programs exclude women, reinforcing their dependency and hindering their empowerment and autonomy. [FN82] Boserup's work sharpened existing "development" theoretical models and inspired various new ones, many of which are based upon an "interrogation of development through the perspective of gender analysis." [FN83]

Development issues are certainly relevant to the African subcontinent, where women are disproportionately impacted by the unequal distribution of material resources, yet it is unlikely that any amount of theorizing will solve these problems. Women, particularly those living in rural areas, desperately need access to economically significant resources such as land and education. [FN84] These deprivations require a practical response. "On a continent [that is] deeply scarred by colonial tyranny, neo-colonial . . military dictatorships, civil wars, poverty and famines" and that is struggling to preserve its traditions from western cultural hegemony, it is understandable why some African women are skeptical of or wholly reject feminism. [FN85]

Yet, while some African scholars reject feminist theory, one might argue that the praxial response of traditional African women to socio-economic and other deprivations reflects the best of, indeed the very essence of, feminist ideals. Gender scholars strongly contend that "women in traditional African societies have always thought and lived in a feminist way," [FN86] that women's movements have a long tradition in Africa, and that "African feminism is partly rooted in traditional African societies." [FN87] Mary E. Modupe Kolawole has remarked that "[a]lthough many African languages have no synonym for feminism as it is defined in the West, the concept of group action by women, based on common 
welfare in social, cultural, economic, religious, and political matters is indigenous $* \mathbf{3 0}$ and familiar to a majority of these women." [FN88]

According to Professor Obioma Nnaemeka:

the majority of African women are not hung up on articulating their feminism, they just do it. In my view, it is what they do and how they do it that provide the 'framework'; the 'framework' is not carried to the theater of action as a definitional tool. It is the dynamism of the theater of action with its shifting patterns that makes the feminist spirit/engagement effervescent and exciting but also intractable and difficult to name. [FN89]

Thus, some argue that the lived experience of African women embodies praxial feminism; these women live beyond the confines of any conceptual frame and confront patriarchal structures through negotiation and compromise. [FN90]

Black African women often are figures of influence not only in the lives of their families, but also in the broader community. [FN91] A number of studies of working-class black African women have shown that these women defy stereotypical assumptions of passivity and dependency as heads of household and political activists. [FN92] Catherine Campbell's research demonstrates that women in black townships often assume the mantle of head of household and are figures of authority in families where men are frequently absent due to political and economic circumstances. [FN93]

Politically, African women also transcend conventions of silence and apathy. In South Africa, women protested and fought alongside their husbands, sons, and brothers as part of the anti-apartheid crusade. Their efforts kept families together, sustained hope in their communities, and inspired dramatic and historic political change. [FN94]

African women, particularly black women, are concerned with issues as basic as access to clean water and housing, issues that have generally not been the focus of theoretical feminist inquiry. [FN95] Faced with all manner of crises, women in Africa have begun organizing their responses to concerns that are relevant for Africans, including extreme poverty. [FN96] Women in Africa are fighting for access to land, the right to own property, control of food distribution, living *31 wages and safe working conditions, improved education and healthcare, and a more active role in the political process. [FN97] With their collective responses to these economic, social, and political issues, ordinary community women also are quietly challenging existing conditions of gender inequality. This process is an important part of finding a uniquely African feminist voice and involves not only the academic effort to reconcile the plurality of feminist theories but also the survival imperative to seek creative solutions to the many problems facing women, their families, their communities, and their states. [FN98]

\section{The Victoria Mxenge Housing and Development Association}

A woman's place is in the home.--Proverb

The women of the Victoria Mxenge Housing and Development Association may not have been directly engaged in the debates about the precise definitional contours of "African feminism." However, the collective response of these women to their material circumstances epitomizes the very essence of feminist thought. The survival imperative inspired the Association to action, an action that has had a profound effect not only on the Association's members, but also on the broader governmental policy initiatives designed to alleviate poverty and homelessness in South Africa's urban areas. This extraordinary group of South African women bravely fought a very personal battle against seemingly insurmountable cultural, political, and economic odds in order to improve their lives and the lives of their families. This section will introduce the Victoria Mxenge Housing and Development Association and the historical context in which it evolved, will reflect upon just a few of the impediments that its members confronted, and will consider the challenges and possibilities that these women and others like them continue to encounter. 


\section{A. The Historical Context [FN99]}

The history of South Africa reveals a pervasive devaluation of women's lives. [FN100] A pronounced gender hierarchy in which females are subordinate operates in traditional African culture. [FN101] Under traditional customary law in South *32 Africa, [FN102] women were virtually invisible in the legal system. Women's rights as citizens were severely limited, particularly in the areas in which women are peculiarly susceptible to gender bias, such as marriage, divorce, inheritance, and succession. [FN103] Under customary law, women were accorded the status of perpetual minors, subject to the authority of men regardless of their age or marital status. [FN104] They could not inherit, own property in their own right, or act as guardians of their children; they could not enter into contracts without the consent of a male guardian, nor could they sue or be sued without the participation of the guardian. [FN105]

Under this system of law, male family members were a woman's guardians until her marriage, after which time her husband assumed guardianship. [FN106] The families of both the husband and the wife were required to consent to their marriage. Their families also negotiated and transferred the bride wealth, or lobolo. [FN107] A woman's husband controlled the joint marital estate under this system, in which a woman retained the status of a perpetual minor. [FN108] The practice of polygamy among some traditional communities also limited a woman's potential interest in and control over marital property. [FN109]

Exacerbating this tenuous situation, divorce often was unavailable to women. Not only were there sometimes no specific grounds for divorce under customary law, but a woman who did not have the support and assistance of her guardian often was unable to pursue a divorce. [FN110] Further, a wife was severely penalized if she attempted to leave her husband; she could lose her children to her husband or his family if she or her parents could not repay or return the lobolo. [FN111]

Women also were disadvantaged under the customary law of male primogenitural*33 succession. [FN112] African women generally were excluded from intestate succession. The eldest son of the family head was the heir, and, thereafter, the eldest son's eldest male descendant was next in line. If the family head died with no male issue, that head's father succeeded to the estate. [FN113] In addition, communal tenure systems generally vested rights in male leaders, and the allocation of land and housing traditionally was to male "heads" of households, further entrenching women's dependency on their relationships to male heirs. [FN114]

The new legal systems imposed upon African societies during the colonial era generally perpetuated the discriminatory elements of customary law. [FN115] Indeed, colonialism destroyed most of even those small vestiges of official power that women commanded in traditional African societies and reproduced the worst of the indigenous patriarchal traditions. [FN116] Colonial law recognized the jurisdiction of customary law in matters of family, property, and succession. [FN117] Not only did this perpetuate the subjugation of black women, but it also affirmed patriarchal prerogatives and further consolidated the authority of elite males. Thus, colonialism further de-equalized black South African women. [FN118] These women were devalued as a result of their gender and also suffered discrimination as a result of their status as "natives." [FN119]

This de-equalization continued during the apartheid era. Apartheid ideology, a military state, and the patriarchalism of nineteenth century Calvinism [FN120] combined with the extant colonial/customary two-tiered legal system to further disadvantage women within South African society. [FN121] As one scholar noted, "the legal and economic edifice of apartheid . . ., both in the public and private $* \mathbf{3 4}$ realms, generated and reinforced the dispossession, discrimination, and subjugation of women." [FN122]

Consider, for example, the apartheid-era Population Registration Act of 1950, pursuant to which all inhabitants of 
South Africa were classified as either white, Coloured, or Native. [FN123] Social rights, political rights, educational opportunities, and economic status were largely determined by an individual's classification. [FN124] Black South African women were relegated to the lowest rung of the racial hierarchy. [FN125]

Apartheid laws and policies also separated black women from spouses and denied these women the right to travel freely to seek employment. [FN126] One such law, the Native (Urban Areas) Consolidation Act 25 of 1945, [FN127] restricted the rights of blacks to acquire land in urban areas and allowed the government to remove blacks from urban districts who did not "serve[ ] the needs of the white man." [FN128] This law, in conjunction with a notorious group of statutes known as the pass laws, [FN129] controlled the labor flow of black South Africans into urban areas and barred them from these areas when they were not working. [FN130] This system "locked [black South African] women into a cycle of dependency" in which many remain trapped. [FN131]

Even when black African women were able to reach the city, they confronted continued discrimination based upon their gender. Legislation that restricted residency to those with ten years of continuous legal employment often *35 prevented women from independently acquiring the right to live in the city. [FN132] Further, because of their status as dependents under Section 10(1)(c) of the 1952 amended Native (Urban Areas) Consolidation Act, [FN133] women were vulnerable to eviction from their homes and to expulsion from urban areas because they were ineligible to acquire legal title or tenancy in their own names. [FN134] In addition, a separate law prevented women from placing themselves on waiting lists for public housing. [FN135] As such, divorce or widowhood often resulted in the loss of residence. Indeed, if a husband died, his wife and children were subject to being removed from the city if his wife did not independently qualify for rights to urban residence under Section 10 of the Native (Urban Areas) Consolidation Act. [FN136] Even if a widow did qualify, she often struggled to retain her right to urban housing. [FN137]

It was not until 1971 that government policy changed to prohibit repossession of houses in cases where widows with children qualified for residence. [FN138] Five years later, the thirty-year leasehold was re-introduced, followed closely by the ninety-nine-year leasehold. [FN139] While ninety-nine-year leases did not grant freehold land ownership, they did guarantee possession and rights of inheritance, and allowed Africans with legal status the right to purchase their homes and to renovate or rebuild them at their discretion. [FN140] The state finally accepted African freehold tenure in urban areas in 1985. [FN141]

Nevertheless, while these were significant advancements, African males were the primary beneficiaries of these reforms, and African women remained at a disadvantage with regard to both leaseholds and freeholds. [FN142] The legal edifice that sanctioned discrimination in matters of housing ensured that public housing was occupied primarily by males, and, when public housing stock was offered for sale, "male tenancy translated into male ownership of those same houses." [FN143] *36 Even when opportunities for home ownership did arise, gendered wage differentials made it difficult for women to access financing. [FN144] To make matters worse, divorced women and widows were denied access to financial assistance for housing purposes if their husbands had ever owned any property. [FN145]

Professor Penelope Andrews notes that, while black women bore the brunt of the negative effects of the apartheid racial hierarchy, all women were disadvantaged to varying degrees in apartheid South Africa. [FN146] The lot of Indian/ Asian and Coloured women was not markedly better than that of black women, and white women too suffered discrimination. [FN147] In her work, Professor Andrews quotes internationally renowned jurist, scholar, and South African Constitutional Court Justice Albie Sachs, who has referred to patriarchy as being "the only truly non-racial institution in South Africa." [FN148]

Despite the gender impact of the tragedy of apartheid, the issue of race dominated the agendas of reformers, obscur- 
ing, if not entirely excluding, gender inequality issues. [FN149] While women were instrumental in the demise of apartheid, their oppositional activities did not immediately advance the cause of gender equality or address gender oppression. [FN150] In fact, women were not admitted as full members of the African National Congress ("ANC") until 1943, [FN151] a circumstance that many attribute to the patriarchal bias of its leadership. [FN152]

During this period in South Africa's history, women activists across organizational boundaries focused their efforts on opposing apartheid. [FN153] The 1954 Women's Charter drafted and adopted by the Federation of South African Women ("FSAW") is illustrative. The Charter not only proclaims its members' solidarity with men in the struggle for liberation, it also declares the organization's intentions regarding gender-equality at least in part from the members' perspective as wives and mothers. [FN154]

Consider also this example. One of the most significant protests in South African history occurred on August 9, 1956, when approximately 20,000 women *37 marched to the Union Buildings in the nation's capital, Pretoria, to protest the above-described Pass Law system. [FN155] This historic event, now referred to as the Women's March, helped to shape present-day South Africa and is commemorated annually in the country as Women's Day. [FN156] Yet, the major women's groups that organized these historic protests were associated with the liberation movements or operated with the specific purpose of resisting apartheid rather than advancing women's rights. [FN157]

As the structures of apartheid began to be dismantled, the quest for racial equality continued to dominate the nation's political and legal discourse. [FN158] The leaders of the anti-apartheid liberation movement, both male and female, still placed women's issues quite low on the transitional political agenda. In its 1988 Constitutional Guidelines, the ANC failed to include a prohibition against gender discrimination within the text of the provision that created a constitutional duty to eliminate racial discrimination. [FN159] Gender discrimination was addressed elsewhere and less prominently in the Guidelines. Article (w) of the Guidelines read, "Women shall have equal rights in all spheres of public and private life and the state shall take affirmative action to eliminate inequities and discrimination between the sexes." [FN160] However, critics argued that this phrasing guaranteed "nothing more than equality between women." [FN161]

Yet, as the negotiations to draft a new South African Constitution began, an organized and assertive women's movement ensured that gender equality was a part of the process. [FN162] The Women's National Coalition ("WNC") was formed in 1992 as a result of the efforts of the ANC Women's League to create a charter to express the ideals that women sought to enshrine in the new Constitution. [FN163] As one of the first organizations in South Africa promoting gender equality, the Coalition's membership included women from across racial, political, linguistic, and cultural spectra. [FN164] From 1992 to 1994, it grew from its original membership of seventy national organizations and eight regional coalitions to ninety-two national*38 organizations and thirteen regional coalitions. [FN165]

Ultimately, the WNC generated a charter--the Women's Charter for Effective Equality--that embodied the priorities of a more diverse array of women throughout the country. [FN166] The Charter included demands to contractual, property, and inheritance rights that had been denied to women under the colonial/customary dually-tiered legal system, [FN167] and called for the right to participate in traditional and community courts and in all traditional institutions. [FN168] The Charter demanded that the state recognize customary marriages and that these marriages be given a legal status equal to that given to other legal forms of marriage. [FN169] On the sensitive points of custom, culture, and religion, the Charter was unrelenting. Although it supported cultural and religious freedom, the Charter stated, "[c]ustomary, cultural and religious practice frequently subordinates women. Roles that are defined for women are both stereotypical and restrictive [.] Women are often excluded from full participation, leadership and decision-making in religious and cultural practice." [FN170] The Charter subjected custom, culture, and religion to the Equality Clause of the Constitution. 
The issue of customary law, however, was a troublesome one for ANC leadership. [FN171] On the one hand, women urged that the Constitution's Bill of Rights be applied to the customary legal system without exception. African leaders, on the other hand, sought to totally exclude customary law from Constitutional or legislative equality mandates, [FN172] fearing that this would threaten the traditional power structures. [FN173] These leaders, most of whom were older males, asserted that customary law merited a new parallel status with the national legal system, maintaining that indigenous systems were sufficiently democratic and $* \mathbf{3 9}$ thus did not require constitutional preemption. [FN174] Because the ANC negotiators perceived that they needed the political support of traditional leaders during the constitutional process, they were attentive to these leaders' demands. [FN175] Thus, the application of the Equality Clause to traditional practices took a compromised form.

Other constraints limited the lobbying efforts of women during the constitutional negotiations. While women were nominally represented in the negotiation process in 1993, a number of delegations either refused the instructions of the Negotiating Council to appoint women or grudgingly placed them in non-speaking roles, thus limiting their influence. [FN176] Even those few women appointees were handicapped by their own political inexperience and often were excluded from the informal constitutional negotiations that took place within the nation's entrenched "old boy networks." [FN177]

Yet, the WNC and other women's groups persevered throughout the negotiation process. They persistently lobbied the major political parties and the drafters of the new Constitution to commit to the principle of gender equality, urging that women's rights be integrated into the nation's plans for reconstruction. [FN178] Persuaded by women activists prior to the 1994 election, the ANC allocated one-third of its parliamentary candidate list to women, thus ensuring the active participation of women in government and in the constitutional drafting process. [FN179]

Nelson Mandela expressed the ANC's commitment to gender equality, acknowledging that "[i]t is vitally important that all structures of government, including the president himself, should understand this fully, that freedom cannot be achieved unless the women have been emancipated from all forms of oppression." [FN180]

This commitment to representational parity has since been honored: women comprised $43 \%$ of the National Assembly in 2009; South Africa has a number of female ministers and deputy ministers. [FN181] Thus, in the end, women's rights activists did succeed in their efforts to incorporate gender equality into the nation's new legal documents and systems. [FN182]

*40 B. The Legal Framework--Women's Rights and The Right to Housing [FN183]

Scholars have opined that South Africa's "formal legal landscape appears very favorable for women.” [FN184] Both the 1993 Interim Constitution and the final Constitution enacted in 1996 enshrine a commitment to gender equality. [FN185] In the Founding Provision of Chapter 1, the Constitution declares that the Republic of South Africa is founded on "[h]uman dignity, the achievement of equality and the advancement of human rights and freedoms [,] . . [n]on-racialism and non-sexism." [FN186] Gender rights also are incorporated in the Bill of Rights, particularly in Section 9. [FN187]

The first part of Section 9 provides that "[e]veryone is equal before the law and has the right to equal protection and benefit of the law." [FN188] Subsection 3 of that Section proclaims that "[t]he state may not unfairly discriminate directly or indirectly against anyone on one or more grounds, including race, gender, sex, pregnancy, marital status, ethnic or social origin, colour, sexual orientation, age, disability, religion, conscience, belief, culture, language and birth." [FN189] Subsection 4 states that "[n]o person may unfairly discriminate directly or indirectly against anyone on one or 
more [of the above-listed] grounds." [FN190] Section 9 also prohibits discrimination by private individuals, obliges the government to enact legislation "to prevent or prohibit unfair discrimination," [FN191] and provides that discrimination on the grounds listed "is unfair unless it is established that the discrimination is fair." [FN192]

Women's rights under customary law, however, are not addressed so directly in the Bill of Rights or elsewhere in the Constitution. [FN193] There are several relevant provisions in the Bill of Rights, including Section 30, which recognizes that "[e]veryone has the right to use the language and to participate in the cultural life of their choice, but no one exercising these rights may do so in a manner inconsistent with any provision of the Bill of Rights." [FN194] The Bill of Rights also states that the rights granted in Section 31, which protects cultural, religious, *41 and linguistic communities and their practices, may not be exercised in a manner inconsistent with the Constitution's guarantees of equality. [FN195] Indeed, the concluding provision of that constitutional chapter requires that courts, tribunals, and other forums promote the spirit of equality embodied within the Bill of Rights when interpreting the Bill of Rights and legislation or when developing the common law or customary law. [FN196] Other provisions of the Constitution also pertain to the interaction between gender equality and customary law. Chapter 12 of the Constitution, entitled "Traditional Leaders," stipulates that "[t]he courts must apply customary law when that law is applicable, subject to the Constitution and any legislation that specifically deals with customary law." [FN197] The language of these constitutional provisions indicates that traditional law and institutions must conform to the principle of equality. [FN198]

To strengthen and effectuate the gender equality principles embodied in the Constitution, the drafters established the Commission for Gender Equality in order to "promote respect for gender equality and the protection, development and attainment of gender equality." [FN199] The Constitution empowers the Commission to "monitor, investigate, research, educate, lobby, advise, and report on issues concerning gender equality." [FN200]

However, while South Africa's formal legal pronouncements may be favorable for women, [FN201] they have not guaranteed the removal of "practical obstacles to political participation, nor [have they] guarantee[d] the achievement of actual social and economic equality." [FN202] If, as many contend, the Constitution's "rhetorical" equality has failed many South Africans, [FN203] particularly the nation's black citizens, it has failed even more conspicuously in areas where women are particularly vulnerable, such as family and customary law, violence against women, education, health care, and employment. [FN204] Many influential policymakers believe that a sizeable proportion of South African women has been denied the opportunity to benefit from constitutionally guaranteed rights as a result of crushing poverty and the scarcity of economic resources. [FN205]

*42 This belief appears to be sound; the gap between the rights promised in the Constitution and the economic conditions in which black South African women live is particularly grievous. [FN206] While they may now be empowered to enter the workforce, women have higher unemployment rates than do their male counterparts, and those who do find work tend to earn less than their male counterparts. [FN207] Nearly $40 \%$ of wage-earning South African women perform unskilled jobs. [FN208] Further, women generally retain responsibility for domestic work in their homes even as they perform wage labor outside the home. [FN209] In the shadow of the constitutional guarantee of equality, women in rural South Africa still perform more than $90 \%$ of all daily household tasks. [FN210] In these areas, women carry water and firewood, and they also perform arduous work in the fields. [FN211] In urban areas, women may be the primary wage earner in a family as well as being charged with childcare and housework. [FN212] Alternatively, these responsibilities for unpaid home and community work preclude many women from seeking or sustaining paid employment. These "interrupted work patterns also negatively impact [women's] ... mobility and earnings in the workplace and ultimately [their] . . . access to credit and their ability to afford housing." [FN213] Thus, despite the Constitution's egalitarian objectives, women, particularly the very poorest women, suffer an existence of subordination. [FN214] 
Poor women fight not for lofty principles of equality but for access to very basic resources such as food, health, education, physical security, and, with particular relevance to the Victoria Mxenge Housing and Development Association, shelter. [FN215] Resources such as these significantly impact a woman's ability to improve her economic circumstances. For example, as previously discussed, customary legal systems allocated property and land only to men and resulted in great inequities for women, [FN216] a situation that South Africa's ambitious housing and land reform program has not yet effectively considered or addressed.

Housing and land reform were top priorities for the new ANC government when it came to power in 1994. [FN217] Indeed, property and housing [FN218] are included $* \mathbf{4 3}$ in the lengthy list of socio-economic rights afforded to all South African citizens under the new Constitution. [FN219] Unlike apartheid-era land policies, the Constitution mandates that "[t]he state . . take reasonable legislative and other measures, within its available resources, to foster conditions which enable citizens to gain access to land on an equitable basis." [FN220] Its Section 25(8) states that "[n]o provision of this section may impede the state from taking legislative and other measures to achieve land, water and related reform, in order to redress the results of past racial discrimination." [FN221] The Bill of Rights also declares that "[e]veryone has the right to have access to adequate housing" [FN222] and that "[t]he state must take reasonable legislative and other measures, within its available resources, to achieve the progressive realisation of this right." [FN223]

To effectuate these rights with regard to land reform, the Constitution identifies several mechanisms; specifically, expropriation and legislative action. Section 25(2) states that "[p]roperty may be expropriated only in terms of law of general application ... (a) for a public purpose or in the public interest . . .." [FN224] The phrase "public interest" is defined to "include[ ] the nation's commitment to land reform, and to reforms to bring about equitable access to all South Africa's natural resources." [FN225] Regarding legislative action to implement land reform, the Constitution's Section 25(7) decrees that "[a] person or community dispossessed of property after 19 June 1913 as a result of past racially discriminatory laws or practices is entitled, to the extent provided by an Act of Parliament, either to restitution of that property or to equitable redress." [FN226] Section 25(6) supplements this remedy by providing that "(a) person or community whose tenure of land is legally insecure as a result of past racially discriminatory laws or practices is entitled, to the extent provided by an Act of Parliament, either to tenure which is legally secure or to comparable redress." [FN227] Despite shortcomings in implementation, $* \mathbf{4 4}$ these constitutional provisions demonstrate the government's commitment to land reform and provide a legal basis for the expropriation of land and for the creation of specific legislation to bring about reform. [FN228]

The post-apartheid government created a new agency, the South African Department of Land Affairs, [FN229] to advance the new Constitution's property and housing aspirations and to implement the land reform goals set forth in South Africa's Reconstruction and Development Programme (the "RDP"). [FN230] The department engaged various stakeholders in an extensive process of public consultation, [FN231] a process that resulted in the publication of an official position paper known as the Green Paper. [FN232] This Green Paper identified three major priorities for the nation's land reform program: (1) restitution, (2) redistribution, and (3) land tenure reform. [FN233] Policy guidance pertaining to each of these areas then was translated into enabling legal mechanisms. [FN234]

Two of these priorities, redistribution and land tenure reform, are particularly relevant to the Victoria Mxenge Housing and Development Association. The first of these, redistribution, is intended to redress the collective grievances arising from South Africa's long history of land dispossession and to provide the poor with access to land for agricultural, residential, and other productive uses in order to secure their tenure and improve their livelihoods. [FN235] While rural agricultural properties have been the primary targets for redistribution, urban property also is subject to this component of the land reform program; it is intended to provide settlement or land acquisition grants to "previously disadvantaged people" [FN236] for the purchase of land. [FN237] 
*45 The redistribution process is being implemented via two principal statutory vehicles. The first, the Provision of Land and Assistance Act 126 of 1993, provides for the designation of land for settlement purposes and for the provision of financial assistance for the acquisition of land and secure tenure rights. [FN238] The second legislative measure, the Development Facilitation Act 67 of 1995, [FN239] was enacted to increase the speed of delivery of land for development projects. [FN240] A range of additional financial and other resources, such as the planning grant and facilitation and dispute resolution services, also are available to complement the redistribution legislation. [FN241] The current government has committed to taking "concrete steps to ensure that housing development contributes to eliminating the duality of living spaces inherited from apartheid," [FN242] and, despite some difficulties, substantial delivery has been achieved in the redistribution plank of South Africa's land reform strategy. [FN243]

Tenure reform is the other component of South Africa's land reform program of particular relevance to the Association. The fundamental goals of tenure reform are to provide individuals with secure tenure, to prevent arbitrary evictions, and to accommodate diverse forms of land tenure, including types of communal tenure. [FN244] Proponents of tenure reform believe that tenure is critical for encouraging individual investment and sustainable use. [FN245]

This priority has been described as the Reform Program's most complex area, [FN246] and several legislative measures have been enacted to address the byzantine laws applicable to, and claims made by, owners, occupants, and tenants to individual plots of land. [FN247] These measures include the Interim Protection of Informal Land Rights Act 31 of 1996, [FN248] the Land Reform (Labour Tenants) Act $3 * \mathbf{4 6}$ of 1996, [FN249] the Extension of Security of Tenure Act 62 of 1997, [FN250] the Prevention of Illegal Eviction from and Unlawful Occupation of Land Act, [FN251] and the Communal Land Rights Act. [FN252] These Acts provide mechanisms for the acquisition of long-term tenure security and for the acquisition and management of property by non-governmental groups and organizations in recognition of black South African notions of communal land ownership. [FN253] The plight of the nation's women receives special attention in the Prevention of Illegal Eviction from and Unlawful Occupation of Land Act. This Act directs that particular consideration be given to the needs and rights of "the elderly, children, disabled persons and households headed by women." [FN254]

Nationwide statistics demonstrate the importance of a new legal regime to address tenure issues. Researchers have reported that some $9 \%$ of South African households, or 780,000 homes, still live in rural areas under "traditional, informal, inferior, and/or officially unrecognized forms of tenure." [FN255] A further 18\% of all South African households, or 1.5 million households comprising 7.4 million people, live without formal tenure rights to their accommodations "in squatter conditions, [in] backyard shacks [,] or in overcrowded conditions in existing formal housing in urban areas." [FN256]

*47 With regard to the constitutional "right to have access to adequate housing," [FN257] the South African government has adopted legislative and policy measures in order to meet this urgent need of its citizens. The RDP, the policy framework document adopted shortly after the ANC came to power in 1994, [FN258] set forth the government's basic housing policy and outlined numerical targets for housing construction. [FN259] The South African government formulated its current housing policy in the White Paper on Housing, published by the government in December of 1994. [FN260] The White Paper interpreted the concept of "adequate housing" through its vision of:

viable, socially and economically integrated communities, situated in areas allowing convenient access to economic opportunities as well as health, educational and social amenities, within which all South Africa's people will have access . . . to [a] permanent residential structure with secure tenure, ensuring privacy and providing adequate protection against the elements; and potable water, adequate sanitary facilities including waste disposal and domestic electricity supply. [FN261]

The 1997 Housing Act is one of the principle pieces of implementing legislation. [FN262] This Act gives priority to 
the housing needs of the poor and requires $* 48$ that the government [FN263] provide a choice of housing and tenure options. [FN264] The Act also obliges the government to support and encourage affected individuals and communities, including co-operatives, associations, and other community-based organizations. [FN265]

Section 4 of the Housing Act mandates that the National Minister of Housing publish a National Housing Code. [FN266] This Code is a compilation of reports, debates, laws, legislation, and government papers assembled into one comprehensive document that provides guidance as to how housing policy should be implemented. [FN267] The Code describes in detail the various housing subsidy instruments available to low income households to access adequate housing and the relevant policies, guidelines, qualification criteria, and norms and standards. [FN268]

In the Housing Code, the government describes a number of programs to finance the purchase or construction of housing, including the Individual Subsidy and the Enhanced People's Housing Process. [FN269] The individual subsidy mechanism [FN270] is among the most important of these vehicles. On an individual basis, qualified first-time property owners with a household income of not more than 3,500 ZAR [FN271] per month can apply for the subsidy. [FN272] Subsidies are modest, 84,000 ZAR, [FN273] and may be utilized to acquire an existing house or a vacant serviced lot associated with a contract for construction through an approved mortgage*49 loan. [FN274] When these subsidies were first created, policymakers envisioned that houses would be delivered through a partnership between governmental actors [FN275] and private developers and designed this program to help finance the construction of large-scale residential developments. [FN276] These developments were designed to resemble existing township layouts and generally were located on the urban peripheries; residents received individual freehold title to "uniform, freestanding, mostly one-roomed houses." [FN277] When conceived, it was assumed that commercial finance would be available to beneficiaries to supplement subsidy funds. [FN278]

The government met its target with these programs [FN279]--a considerable achievement--but the delivery has not been without problems. Both the infra $* \mathbf{5 0}$ structure and building structures often were of poor quality, and houses also were very small in size. [FN280] Furthermore, the development sites were located in greenfield areas remote from urban centers, reinforcing the segregated geography of South African cities during apartheid. [FN281] This geographical placement not only increased already high transportation costs and compounded employment challenges, but it also resulted in social and economic isolation. [FN282]

Several additional legislative and programmatic initiatives have been adopted in response to these challenges, including the Cabinet-approved "Breaking New Ground: A Comprehensive Plan for the Development of . . . Sustainable Human Settlements" (BNG). [FN283] These programs were intended to, inter alia, accelerate housing delivery, utlize housing as a job creation strategy, and improve the quality of life for the poor. [FN284] In 2005, the Government also entered into a Social Contract for Rapid Housing Delivery with banks and property developers in order to remove obstacles to housing delivery and to invest more resources in low-cost housing. [FN285] Additionally, the passage of the 2008 Housing Development Agency Act [FN286] created an eponymous agency that is tasked with assisting local municipalities to acquire and develop "appropriately located" land for sustainable residential or community development. [FN287] Further, the Housing Code was revised in 2009 to accommodate policy shifts set forth in the BNG plan from the provision of housing only to the establishment of sustainable human settlements and to respond to the significant changes in demand for housing in South Africa due to population growth, large increases in the number of households, and high rates of urbanization and unemployment. [FN288]

Yet, many still are waiting for homes. [FN289] While subsidies are an important *51 financial resource with which women like the members of the Victoria Mxenge Housing and Development Association are able to secure housing, [FN290] the relatively small monetary value of these subsidies limits their impact on housing conditions, a result that has 
"particularly serious implications for women in light of the challenges they face in accessing credit and finance." [FN291]

Thus, while seemingly entitled to share with men the benefits of the nation's housing and land reform initiatives, women do so within the existing patriarchal structure. [FN292] The failure to address this conflation of structures often perpetuates women's oppression.

The South African government also adopted The Rental Housing Act [FN293] to acknowledge that individual home ownership is not always possible or appropriate. This Act promotes a rental housing market and addresses landlord and tenant rights and responsibilities. [FN294] A robust and regulated rental market is important for women because, given their economic status and historical lack of access to, or ability to finance, property ownership, rentals often are their only available housing option.

While the government's efforts to increase access to adequate housing have met with some success, these legislative and policy developments have not yet solved the housing crisis in South Africa. These efforts notwithstanding, there reportedly remain four million homeless individuals across the country. [FN295] The South African government admits that there has been a "massive increase in the number of households forced to seek accommodation in informal settlements, backyard shacks and in overcrowded conditions in existing formal housing." [FN296] As one official noted, "roughly $80 \%$ of urban residents . . . [live] in slum conditions and . . . this population of slum dwellers is expected to increase to 1.4 billion by 2020 . . . More than 200 million people became new slum-dwellers in [South African] cities and towns in the decade between 1990 and 2001." [FN297]

In 2009, Tokyo Sexwale, South African Minister of Human Settlements, warned that South Africa is "confronted by a grotesque form of urbanization, with an alarming increase of informal settlements which can turn into a potential $* \mathbf{5 2}$ human calamity. To date, there are more than 2800 of such settlements across the country, where people live in abject poverty where we have experienced some recent violent service delivery protests. The conditions there are inhuman." [FN298] In Cape Town, some estimate that nearly one-third of the city's population live in slums or squatter settlements. [FN299]

Vulnerable and disadvantaged women figure prominently in these statistics because of previously described systemic factors, including customary law, the practice of polygamy, current land ownership patterns, and poverty. The resulting gender-specific issues present a challenge to reformers. However, fulfillment of the constitutional promise of access to adequate housing [FN300] requires that these issues be confronted and that there be formal recognition of the large number of female-headed households. [FN301]

Women have suffered disproportionately in the country's rapid push toward urbanization and industrialization, its widespread community resettlement, its dramatic population shifts, and its HIV crisis, and the nation's women often are still mired in poverty, homelessness, and hopelessness. [FN302] Many South Africa women have inferior educations and low self-confidence, and many of their own communities have yet to fully acknowledge the distinctive experience of their oppression. [FN303] While legal rights to gender equality "might serve an important normative function, ... . [they do] not in and of [themselves] inevitably transform women's lives." [FN304]

\section{The Association}

Just as it failed many other black women in post-apartheid South Africa, the new Constitution did not immediately transform the lives of the members of the Victoria Mxenge Housing and Development Association. The Association was 
organized in 1992 by a small group of women who lived in the informal settlement of Khayalitsha (pronounced org]). [FN305] Khayalitsha, which translates*53 from Xhosa to "New Home," is one of the largest informal settlements in the Cape Town area and is located some distance from the city on a sandy flood plain known as The Cape Flats. [FN306] It is one of the most disadvantaged communities in Cape Town.

The mere creation of the Association was itself a significant achievement. Theorists posit that civil society groups generally only exist in a context where there is "an inclusive legal constitutional framework, inclusive legal citizenship, a culture of rights and duties, inclusive representative democracy, a culture of political tolerance, formal legal equality of all individuals, and a legitimate government and state." [FN307] These conditions did not exist in South Africa during apartheid. [FN308] Their absence posed particular difficulties for women's groups and other groups committed to community development, members of which often lacked the skills necessary to become effective advocates and partners. [FN309] Civil society in South Africa primarily existed to resist colonialism, then apartheid, [FN310] and its component organizations reflected the stratified social exclusion existing in the nation's society at large. Thus, "'[t]he heritage of community development, in its context of colonialism, racism, apartheid, sexism, and repressive labour policies is one of piecemeal efforts of non-government organisations (NGOs) and the restricted programmes of government departments."' [FN311]

Given this heritage, the formation of the Association is all the more remarkable. Most of the Association's founding members were women who headed their households and had no formal education. [FN312] While many were unemployed, those who did have income engaged in domestic work, fruit and vegetable sales, and childcare. [FN313] These women struggled daily with basic needs such $* \mathbf{5 4}$ as food and physical security, health, education, and shelter. [FN314]

Shelter is "one of the most fundamental needs of human beings--a place where they can live safely and securely." [FN315] This need was particularly acute for the members of the Association. Many of the founding members had survived the forcible removals and demolitions of the apartheid era, [FN316] and most had inhabited poorly-erected shacks for decades before their saving scheme enabled them to build and own their own homes. [FN317]

The conditions in which they lived were appalling. The founding Association members lived like many others in shacks in South Africa's massive informal settlements--settlements that are "cobbled together from scraps of metal, mismatched planks of wood, old signs, cardboard, and other found and recycled materials ... [with] no running water, no sewage, sometimes no electricity, and certainly no privacy." [FN318] For example, Boniswa Kuse lived in a one-room shack with two of her children. [FN319] The structure stood in the backyard of a small house and lacked even the most basic amenities. [FN320]

Mildred Mqwathi's plight is representative of women seeking housing under post-apartheid housing policies, and she was one of the more fortunate. While her pre-Association "home" had only one room and a bathroom, it was a house, and even a small house offered greater security than the shack in which she lived for twenty-eight years. [FN321] In this small space, Mildred cares for nine others, seven of whom are her children and two of whom are her grandchildren. [FN322]

The land and housing reform efforts in democratic South Africa offered these women hope that they might finally have an opportunity to satisfy their need for shelter. Yet, as is frequently the case for the poor, there are very few opportunities to obtain mortgages or other homeowner loans from financial institutions. [FN323] Women who engage in homebased work or who otherwise are informally or self-employed often have difficulty accurately estimating their incomes, as this work often is unpredictable or sporadic. [FN324] In such cases, *55 conventional lenders have difficulty verifying employment or accurately estimating income, and the resulting loans often are high risk and much less profitable. 
[FN325] Further, even were loans available from formal lending agencies, many poor borrowers are reluctant to assume the debt, as debt service may endanger their economic viability and further entrench them in their impoverishment. [FN326]

In the absence of formal lending options, the members and advisors of the Victoria Mxenge Housing and Development Association were forced to explore creative and non-traditional funding schemes to support their dreams of homeownership. As they searched, they found a space in the legal complexities of the government's housing scheme from which to transform their purely mental initiatives into a substantial physical community. [FN327]

The Association named itself and its housing site after Victoria Mxenge, an anti-apartheid lawyer who was assassinated in 1985. [FN328] The first members of the Association were inspired by a group of women from the Mahila Milan women's collectives in India who visited South Africa in 1991. [FN329] Mahila Milan pioneered a savings-and-credit group scheme that had a significant impact on housing initiatives in Mumbai, and their South African counterparts were eager to try to replicate the Indian women's success in Cape Town. [FN330]

Building upon existing informal social networks, Victoria Mxenge members relied upon participation in a selforganized savings association to supply the funds necessary for the group's community project. [FN331] Sometimes called an "umgalelo," or a local rotating credit association, [FN332] the Association's savings *56 scheme is elegant in its theoretical simplicity. The cooperative required that its members save on a daily basis, and the group met weekly. [FN333] Volunteers from the Association acted as treasurers-- collecting money from the members, recording transactions, and depositing the money in a dedicated bank account. [FN334]

The Association did not establish formal contribution rules, and members saved what they could, with some saving as little as ten to fifty cents per day. [FN335] Each member had an individual savings book in which her contributions were recorded; there was a separate savings book in which the Association recorded its group transactions. [FN336] These mostly small sums were then pooled, and the accumulated funds and resulting earnings enabled the Association to purchase land. These funds then served as the collateral for loans which, when paired with government grants, enabled members to build houses of their own basic design. [FN337] Members applied for loans from the savings pool and were funded based on each member's individual savings record. [FN338]

The elegance of this system notwithstanding, the Association confronted a number of practical impediments. For example, virtually all of the Association's original members were functionally illiterate or spoke little English. [FN339] Yet, these brave women rose to the challenge by relying upon one another to preserve financial records and to engage external actors in support of their communal goals. "[S]aving as a group effort rather than as individual resource mobilisation makes the saving groups a mechanism for collective mobilisation and identity formation. ... This idea is expressed in the slogan: 'When we collect money, we collect*57 people'.” [FN340]

With the savings collected, the founding membership took nine months to identify and negotiate the transfer of a suitable plot of land on which to build the Victoria Mxenge community. [FN341] The land, owned by the Catholic Church, was located in Philippi, Cape Town, an area approximately six miles from the center of Cape Town, near Guguletu. [FN342] Shortly after securing title to this property, the group began designing a layout for its new neighborhood.

From the settlement's first house, built by the group in 1996, the women have participated in all aspects of their home-building projects. [FN343] They engaged in the planning process, [FN344] actively participated in purchasing materials, and ultimately contributed their "sweat equity" to the construction of every house in the settlement. [FN345] Once a member of the group was ready to start building, the Association constructed a cardboard model and, later, a lifesize model, of the future house. [FN346] With help from a volunteer technical team, the group used the model to estimate 
the cost of the house, to draw up a plan for soliciting contractor quotes, and to solicit those quotes. [FN347] The membership collectively made the final decisions concerning how and when to proceed with construction. [FN348]

*58 Association members, working together, also provided the labor on each house. Their labor was critical to the success of the settlement, as reports suggest that contracting services, a male-dominated industry, were "at best uneven in delivery and quality, and at worst, corrupt and hazardous." [FN349] An unregulated construction industry made it difficult for Africans to secure reliable and/or affordable contractors. [FN350] Thus, members circumvented such obstacles by relying on their own labor and materials. To reduce the number of services they had to contract out, the membership dug the trenches for electricity and phone lines themselves and hooked up their own water and sewer connections. [FN351] Members often poured concrete, made blocks, framed windows, and took care of the painting, plastering, sawing, and hammering themselves. [FN352]

The houses they constructed vary in size and design depending upon each member's contribution. [FN353] Most are one of three sizes: 580, 700, or 775 square feet. [FN354] Some homeowners have even added an additional floor to their houses if their plot is small and they need or want to increase their living space. [FN355] Each house has internal water and sewage connections. [FN356] Reports indicate that the $* \mathbf{5 9}$ average cost of a home in Victoria Mxenge is 12,000 ZAR [FN357] (approximately \$1,705 USD). There are now more than 600 houses in various stages of construction at Victoria Mxenge and at its sister communities, Hazeldean and Vukuzenzele. [FN358] The Association has also purchased additional land on which it hopes to build even more homes. [FN359]

When members' loans are repaid, the funds go back into the community, [FN360] a system that has allowed the group to turn the development into "a small oasis in a seemingly endless sea of shack dwellings and squalor." [FN361] Victoria Mxenge has electricity, water and sanitation, and a mobile clinic. [FN362] "Some of the houses have small garden patches[,]" and the neighborhood boasts a community center, a small shop, and a facility that provides child care for working mothers. [FN363] There is a community choir, and the younger women have designed a savings plan for educational purposes. [FN364] Not only have the community women started a small pottery, but they have also organized an income-generating enterprise to cultivate Arum lilies for the commercial market. [FN365] Some residents also are training as tour guides and are involved in an arts and craft project at a nearby tourist center. [FN366]

*60 The Victoria Mxenge community is much more than a collection of physical dwellings. [FN367] It is a new conceptual project and a model of the power of collective action, one constructed dream by dream and brick by brick by the women of the Victoria Mxenge Housing and Development Association. Their theoretically simple project was a matter of survival and a labor of love, and it provided both challenges and opportunities to the Association's members and to the South African government.

\section{Challenges and Corollaries}

The Victoria Mxenge Housing and Development Association now has more than 280 members, the vast majority of whom are women. [FN368] The model developed and implemented by the Association has resulted in numerous positive consequences both for its members and for other similarly situated South Africans. [FN369] For the members, recognized property rights offer not only a previously unimagined level of legal protection, but also a measure of stability and security. In addition, property ownership provides collateral for market rate loans for home improvements and, in some instances, for entrepreneurial activities. [FN370] A female member's property rights are equivalent in every way to a similarly situated male's rights, making real the gender equality provisions espoused in the Constitution.

On a more basic level, however, the problem-solving competencies developed by Association members as they 
planned and constructed their new homes and community extend far beyond the borders of their land. Members acquired the capacity to assess their own needs and to access external interventions, resources, and partners. [FN371] These individuals also mastered a range of skills, including*61 "housing design, construction and finance, brick making, toilet construction, crafts and a range of other competencies including bookkeeping, census enumeration and information gathering (for example, self-surveys[ [FN372]]), methods for identifying vacant land through physical mapping and visits to the deeds offices, and the development of negotiation skills in order to secure land from the state." [FN373]

These competencies have empowered Association leaders and community members as they more confidently engage in the political process and in the economic life of the nation. In the typology of socio-political governance, the status of the Association is no longer that of an "outsider;" rather, it is now a "threshold" group whose actions have influenced governmental policy even as the group maintains distance from the government and challenges the status quo, particularly at the local level. [FN374] For example, the Association and its national network publicly criticized the government's capital housing subsidy, yet it "frequently negotiated with government on establishing innovative means for accessing public and private finance. ..." [FN375]

*62 As posited in public policy discourse, active citizen participation creates positive social capital; participatory interactions result in a more robust democratic society. [FN376] Indeed, one of the founding members of the Association, Patricia Matolengwe, went on to become the national chairperson of the South African Homeless People's Federation [FN377] and was recognized for her achievements as South Africa's National Housing Person of the Year in 1996 and 1997 and as a finalist for the 1997 Woman of the Year award. [FN378] Ms. Matolengwe also has *63 been recognized by the United Nations for her role in alleviating poverty. [FN379]

Further, the success of their construction scheme has motivated the members of the Association to address other problems that they face. Younger members, for example, have organized a second savings scheme to meet their educational aspirations. [FN380] The community also is tackling issues such as education, unemployment, teen pregnancy, alcohol abuse, and domestic violence. [FN381] Association members report that their entire system of values has changed: "When we were living in informal settlements, we would be pushed around. It was really not living." [FN382]

The work of Victoria Mxenge members also has had an impact on neighboring communities and individuals. Not only do members share their financial planning and building skills with those similarly situated, but their revitalized and upgraded community enhances the value of local property and encourages a more robust and healthy housing market. Their self-build program also sources local labor, smaller contractors, and local material suppliers, further benefiting the surrounding community. [FN383]

The Association's savings cooperative also has inspired similar saving collectives elsewhere in South Africa, [FN384] participation in which will allow other similar groups to pursue their dreams. [FN385] Such savings schemes or informal savings and loan associations know their communities intimately and often are better positioned than formal financial institutions to assess an individual's credit-worthiness. [FN386] These schemes may even serve to attract more favorable financing *64 from formal financial institutions by absorbing much of the administrative cost that financial institutions maintain prevents them from serving the poor. [FN387]

Furthermore, the perseverance and success of the Association and groups like it have had an enormous impact upon South African housing policy and practice. Initially, the government created a standardized capital subsidy program to finance formal settlement of the urban poor. [FN388] This subsidy entitled low-income beneficiaries to freehold tenure of a "uniform product" consisting of a very basic housing structure on a standardized, serviced plot. [FN389] Politicians and administrators made all decisions regarding subsidized housing, and there was no opportunity for "customizing" the 
subsidy's delivery or the product itself in order to address individual circumstances or requirements. [FN390] Indeed, many provincial governments allocated capital subsidy funds to large developers to provide for a more rapid mass delivery of the standardized housing project. [FN391]

Not surprisingly, this standardized "one size fits all" program did not address the needs of all beneficiaries for whom it was designed. While beneficiaries may have been provided with a physical structure, this structure often was of poor quality [FN392] or was unrealistically small. [FN393] Furthermore, the program did not provide the means to maintain or improve it in conditions of extreme poverty. [FN394] According to one commentator, "in many cases unemployed recipients of the . . government housing subsidies end[ed] up selling their subsidy houses for extremely low prices and moving back into informal settlements because the houses [were] too small and they [could not] afford to extend using formal building materials, and/or . . . afford to pay rates and service fees." [FN395]

The Mxenge group did not accept the government's standardized product. Instead, the members designed their own model, then engaged and negotiated with formal institutional structures for official approval of this model. [FN396] When they began their project, their planning and development process differed significantly* $\mathbf{6 5}$ from the process employed in official government programs. Yet, while the group apparently received little or no assistance from its local council, [FN397] the regional and national governments recognized, and continue to recognize, the Mxenge group and organizations like it. [FN398] Data indicate that the market value of the houses constructed by the Association and similar groups exceeds the value of the subsidy received and, in contrast to much of the privately developed state housing in South Africa, is "worth considerably more than the resources put into it." [FN399]

The Victoria Mxenge community and similar projects influenced South African government policy in several significant ways. First, the government has encouraged developers participating in subsidy-funded construction to increase the size and quality of the housing product that they deliver. [FN400] In the early days of the government's land reform efforts, it implemented a housing strategy that utilized technocratic planners and commercial housing contractors and focused on the short-term goal of quickly delivering large numbers of housing units. [FN401] Housing policy has since shifted away from the hasty mass-delivery of one standardized housing product to the provision of housing that incorporates the "concepts of sustainability, poverty alleviation, and housing quality[.]" [FN402] Projects such as Victoria Mxenge have been instrumental in enlarging the official conceptual frame to include more participatory and democratic housing mechanisms. [FN403]

To address quality issues for those aspiring homeowners who do not choose or are unable to emulate the Association's self-help ethos, [FN404] the government*66 passed the Housing Consumers Protection Measures Act 95 of 1998 ("HCPMA") to protect consumers from unscrupulous contractors and developers. [FN405] Many women complained of theft and shoddy workmanship by some contractors and ultimately relied upon their own informal observations and existing social networks to select builders rather than consulting with any regulatory or state bodies. [FN406] To provide some assurances of quality, the HCPMA established the National Home Builders Registration Council ("NHBRC") to provide housing consumers with warranty protection against defects in new homes. [FN407] All builders are required to be registered with the NHBRC, and private mortgages and government subsidies may only be awarded to homes and projects enrolled with the Council. [FN408]

For those who do embrace the Association's self-help ethos, the government has created a specific category of subsidy in the Housing Codewhich is now called the Enhanced People's Housing Process ("EPHP"). [FN409] According to the terms of the national People's Housing Process, community-based organizations such as the Victoria Mxenge group are encouraged to "take the initiative to organise the planning, design and the building of--or actually build--their own houses." [FN410] In this way, the Association's efforts influenced in part how the South African government discharged 
its constitutional obligations. [FN411]

Housing reforms explicitly adopt "a programmatic process to entrench participation*67 of women in the housing-delivery value chain." [FN412] The government has even created an annual "Women's Build" event in honor of the historic 1956 Women's March. [FN413] Similar to Habitat for Humanity projects, volunteers for the Build construct houses in poor communities for the elderly, for households headed by women, and for disabled women caring for orphans or other vulnerable children. The objectives of the Build include raising "consciousness about the construction sector and women's role in it; ... [demonstrating] how cooperative governance and partner institutions support ... the women in housing initiatives; [and promoting] women's access to economic opportunities within the housing sector[.]" [FN414]

Further, based upon the success of groups like the Association, governmental planning and development agencies have begun to involve many stakeholders in their activities in order that a variety of groups have the opportunity to express their needs. [FN415] One official noted enthusiastically: "If you've involved people initially from the planning process to the completion of their home, they get attached to that structure because they've added what we call 'Sweat Equity'. They've made sure that they've participated in acquiring their own home." [FN416]

The government also appears to approve of the revolving function of pooled resources and to be moving towards making savings a more significant component of its program of subsidies, a move that some attribute directly to the success of projects such as the Victoria Mxenge Association. [FN417] When resources for projects are limited, groups must compete, but pooled, stable savings funds such as that organized by the Association attract government finance. [FN418] Because the group shares its expertise and successful development methodologies with peers that have similar goals, these other organizations ultimately require fewer governmental resources. Armed with a well-organized model that has a record of success, groups are better equipped to engage the formal structure of government. [FN419]

Cooperatives such as the Victoria Mxenge Housing and Development Association may positively impact the personal savings decisions of many South *68 African citizens. Because an applicant's savings record is one factor considered by the government in its housing subsidy allocation system, a cooperative's savings requirements arguably may increase a member's sense of responsibility and accountability concerning personal finances. This, and the possibility of community censure if one fails to make a savings contribution or to repay a loan, [FN420] could raise the savings rate and control expectations with regard to the availability of government assistance. [FN421]

Despite these favorable outcomes, not all of the consequences associated with the Association's work have been positive. The process can only serve a few members of a group at a time, and as such, only a modest percentage of the Association's full membership has obtained housing, [FN422] and this at a relatively slow pace. Further, while home ownership does provide those few benefited Association members with legal protection, stability, and security, its cost may effectively make them immobile, tied by debt obligations, both legal and moral, from which they cannot extract themselves. [FN423] Also, the Association's daily savings requirements may discourage the very poorest and most destitute from participating in the scheme, reducing their ability to obtain governmental subsidies or other support.

Furthermore, while members' housing has improved, not all of their problems and challenges have disappeared. For example, the settlement's location still is quite a distance from the Cape Town Central Business District and from the more affluent residential neighborhoods where a number of the Association's members work. Many members endure a long daily commute to work, and, as public transport is unreliable if not wholly inadequate, they spend a substantial part of their earnings on "share taxis." [FN424] Even this form of transport sometimes does not get them all of the way to their place of employment, and, as such, they still may be forced to walk long distances. [FN425] This siting issue is not unique to the Victoria Mxenge development and continues to vex South African officials. Because the price of land in 
urban centers is higher than in peri-urban, suburban, and rural areas, new developments often are located on peripheral land at a substantial distance from economic opportunities, "reinforcing the spatial and racial distortions of apartheid and entrenching poverty." [FN426]

*69 In addition to these inter- and extra-community "physical" challenges, the Victoria Mxenge Association has confronted interpersonal concerns regarding gender relationships. During the initial stages of the process, community men reportedly were skeptical of the project and of the women who initiated it. Though these women obtained skills in all aspects of house building and built their homes themselves, their efforts earned them the ridicule and even antagonism of some males in their communities. [FN427] Of the 286 members of the saving scheme in the late 1990's, only six were men. [FN428] While many argued that the project had the potential to exacerbate strained gender relations within the black population, [FN429] the original members were very firm that only the women could own the houses funded by the Association to ensure long-term security for themselves and their children, a reasonable demand given the tenuous position that women historically held in South African legal and customary systems. A few men have, however, participated in the building project. Yet even within this small cohort, some have demanded to know what "they will get out of it. This is a huge problem in the community." [FN430] This attitude caused conflict within the membership.

Women also have acquired the ability to access and manage financial resources, another factor that has changed their role in the community [FN431] and perhaps further threatened existing patriarchal norms. Many caution that, in the new South Africa, women's empowerment should not result in the disempowerment of men, [FN432] and this perceived marginalization of African men in the Victoria Mxenge domestic economy and civil society may undermine the power of the project's transformative model.

Tensions also exist between the Victoria Mxenge community residents and their neighbors in adjoining settlements. Observers note that it is difficult to ignore the stark contrast between the homes in Victoria Mxenge and those in its neighboring settlement, Vlei. [FN433] The Vlei settlement "is a typical tin-shack settlement. The toilets are tiny tin structures built individually. When the pit gets full, they are abandoned and another structure is built. There is no running water[,] . . . [and] [t]here are few shops." [FN434] Compare that with the Victoria Mxenge *70 community, which is fully serviced and has amenities such as some small garden patches, a community center, and a daycare. Not surprisingly, some Mxenge residents feel unwelcome in Vlei: “They don't like us," one resident opined. [FN435]

Concerns such as these often surface in response to any social experiment. However, the women of the Victoria Mxenge Housing and Development Association are justifiably proud of the success of their project and its demonstrated positive societal impact. It must be hoped that, rather than criticizing the Association's accomplishments, future administrators, regulators, and commentators will focus on addressing all valid concerns and on facilitating the efforts of women's groups motivated to improve the circumstances of their members and the communities in which they live, both physical and social.

\section{Possibilities}

There are a number of ways in which the government has supported, and could continue to support, the aspirations of women such as those involved in the Victoria Mxenge Housing and Development Association. While its EPHP and other group and project-linked programs are excellent first steps, various levels of the South African government might consider implementing additional programs to facilitate self-help building, expanding existing programs, or removing obstacles to the achievement of self-help building projects.

Providing access to credit and financing to the "poorest, the precariously employed, and unemployed" [FN436] 
would significantly advance the government's housing agenda. Previous efforts in this regard have included offering generous incentives to banks to extend loans into low-income markets. [FN437] For example, several joint ventures between banks and government were created, such as the National Housing Finance Corporation, an entity designed to help lowincome applicants enter the conventional mortgage market, and the National Urban Reconstruction and Housing Agency, which guaranteed direct credit to low-income households and bridge financing for developers. [FN438] The government also has worked with banks to create a number of subsidiaries under the National Housing Finance Corporation. [FN439] These efforts largely appear to have failed, however, and the very poor still cannot access conventional credit markets. [FN440]

In response to these failures, calls have been made to create official mechanisms to supplement government subsidies with private sector funding. [FN441] Suggestions also have been made for the creation of a National Housing Bank and for the promulgation of legislation modeled on the United States' Community*71 Reinvestment Act [FN442] that would require financial institutions to meet minimum housing-related lending targets to low-and medium-income borrowers. [FN443]

With regard to the actual construction process, tax incentives or programs that offer governmental contracting preference schemes might be offered to material providers and contractors in order to make reliable and affordable material, labor, and expertise available to land reform program beneficiaries. The government also might consider strengthening and expanding the authority of the NHBRC to monitor and penalize contractors failing to comply with their obligations under the Housing Consumers Protection Measures Act or the requirements of the NHBRC. [FN444]

Policymakers should consider strengthening and enhancing the government's initiatives to involve women more directly in the construction process. The government could offer tax incentives, or even set-aside programs, for female contractors working on government projects. While current housing programs include a "clear $30 \%$ annual participation quota[,] . . [ [t]he few women who made strides found themselves faced with various challenges in the housing construction sector." [FN445] More could be done to offer skills training and to encourage the creation of women-owned construction companies. The development of this segment of the construction industry might provide a greater selection of qualified service providers to those seeking to utilize government grants or other funds for housing projects. The creation of the South African Women in Construction organization offers reason for optimism in this regard. [FN446]

*72 Another possibility is to shift from the current focus on individual household applicants toward improved access to subsidies or grant funding for groups planning housing projects. Prior to the 2009 Housing Code revisions, the application for project-based subsidies had a reputation for being virtually unmanageable. [FN447] Projects qualifying for this type of subsidy involved a wide range of parties, including the potential residents of the proposed community, local governmental authorities, and the developer. These parties not only were required to negotiate a binding Social Compact Agreement, [FN448] but they also were required to demonstrate a host of project details in their subsidy application, including the availability of suitable land and services, the financial viability of the project, and the qualifications of the developer. [FN449] Even if the application were successful, the developer then had to complete various project milestones before subsidy funds are released. [FN450] This generally necessitated bridge finance, and few community-based self-build groups were able to qualify to obtain such financing from traditional commercial lenders. [FN451] Streamlining the application process and offering, or providing security for, bridge loans might make this type of subsidy more accessible. [FN452]

One problem common to all lower-income housing projects is the cost of purchasing suitable land. Experts note that "legal access to land, not even to speak of well-located land, is one of the main barriers to ... house-building capacity." [FN453] Government land acquisitions are largely market-based, and well-situated land is priced beyond the means of 
housing reform beneficiaries. [FN454] In an attempt to facilitate and fast-track the acquisition of land, the Housing Development Agency Act of 2008 established the Housing Development Agency. [FN455] One of the goals of this new agency is to identify, acquire, hold, develop, and release state, communal, and privately owned land for the creation of sustainable residential settlements. [FN456] It is too soon to judge the efficacy of the new Agency, established only in April 2009, but, despite funding challenges, initial progress reports have been fairly well-received. [FN457]

*73 In conjunction with, or in addition to, the work of the new Housing Development Agency, the South African government might consider exercising its constitutional authority to expropriate land to facilitate the development of these types of projects. The Constitution provisionally authorizes the government to expropriate private property "for a public purpose or in the public interest; . . . subject to compensation . . . which ha[s] either been agreed to by those affected or decided or approved by a court." [FN458] The phrase "public interest" is defined to "include[ ] the nation's commitment to land reform, and to reforms to bring about equitable access to all South Africa's natural resources." [FN459] The Housing Development Act explicitly references this expropriation power as it pertains to the Agency's objective of creating sustainable human developments. [FN460]

The Constitution further explicates the term "compensation," stating that the amount, the timing, and the manner of payment of compensation "must be just and equitable, reflecting an equitable balance between the public interest and the interests of those affected." [FN461] For clarification, the provision elaborates a number of circumstances relevant to the compensation determination, "including ... (a) the current use of the property; (b) the history of the acquisition and use of the property; (c) the market value of the property; (d) the extent of direct state investment and subsidy in the acquisition and beneficial capital improvement of the property; and (e) the purpose of the expropriation." [FN462] From a practical standpoint, the location of land must be carefully considered in order to address the locational disadvantages of peripherally located, segregated housing schemes. [FN463]

Beyond the need for the development of new programs or policies, existing programs and processes could be improved or utilized more effectively to advance South Africa's property and housing goals and to make their implementation more gender-sensitive. Making resources available to groups like the Victoria Mxenge Housing and Development Association is only part of the challenge. More fully functioning partnerships between beneficiaries and government are needed in order to provide more targeted distribution and development of state and other agency resources. [FN464]

Scholars and commentators have provided various suggestions for strengthening such partnerships. One such suggestion is to help community-based networks, particularly those comprised predominantly of women, to identify and address their own unique needs and to strengthen their capacity to negotiate with external actors to extract resources. Another set of recommendations $* \mathbf{7 4}$ involves increasing micro-enterprise and employment opportunities to reduce poverty, as well as expanding resident-managed improvements to minimize state expenditures on housing and basic services. [FN465] Policymakers appear to have incorporated many of these suggestions into existing and new housing programs, advancing the concept of housing citizenship. [FN466]

State institutions and development organizations often do not know how to partner with low-income communities, and their interactions therefore often do not achieve concrete or satisfying results. [FN467] External agencies and local communities do not always agree upon a particular community's needs or priorities. This divergence can lead to disappointment and project failure. Agencies may make unilateral decisions should they feel that they are not receiving adequate community support or involvement; community members, particularly poor women, may disengage if they feel that their needs are not being considered or met. [FN468]

Housing professionals sometimes have presumed that the housing needs of men and women are identical, and relev- 
ant policies and strategies often reflect this assumption. [FN469] These professionals should receive training or information that sensitizes them to the particular needs of women with regard to housing, including the role that the concept of a "traditional family" plays in housing practices, the impact of patrilineal succession, polygamy, communal tenure, and the minority status of women under customary and religious law on a woman's access to housing, the way in which male cultural paradigms define "adequate" space and location, and the consequences to women of dealing with domestic violence and HIV/AIDS when seeking housing. [FN470] It also has been suggested that housing data should be disaggregated along gender lines in order to produce more "sensitive" and accurate results. [FN471] Some improved sensitivity to these issues can be seen in projects such as the Women's Build, [FN472] but these projects alternatively may be seen as incremental progress or even as mere token gestures.

Improved education for governmental officials on social and psychological processes and on communications also may avoid the disappointing results of poorly-informed interactions between service providers and beneficiaries, as may a move away from a deadline-driven approach to projects to one more oriented $* \mathbf{7 5}$ toward the measurement of outcomes.

The creation of a legal architecture that implements South Africa's constitutional commitments to gender equality and housing is an ongoing project, and the South African system continues to evolve in response to national conditions and to the work of groups like the Association. The development of organizational capacity also is a long-term process that requires patience and flexibility. This is true for both governmental actors and for groups of "triply oppressed" [FN473] poor black women in South Africa with its apartheid legacy of apathy and interventionist policies.

\section{Conclusion}

It takes a village to raise a child.--African proverb [FN474]

It takes a woman to raise a village.--Adaptation

As feminist theory continues to evolve in Africa, the discourse must respond to the unique material conditions that confront women on that continent. Most African women remain untouched by the evolving feminist dialogue. Indeed, poor women often are skeptical of, if not hostile to, those who seek to define the terms of their emancipation when the poor do not have housing, food, water, or access to employment, educational opportunities, or health care. [FN475]

If the feminist project is to be more than an intellectual exercise for critiquing political, economic, or socio-historical structures, it must engage seriously and openly with the experience of African women [FN476] and must unite the academic, the political, and the practical. [FN477] A conjunctive process may enable African women to craft a version of feminism that is "culturally sustainable" [FN478] and that reflects their experiences and interpretations of their own realities. [FN479] Western/northern and other "labeled" scholars engaged in the project to locate feminist theory within the African context must take care that they do not become part of the disempowerment of their African counterparts by attempting to articulate or define African feminism. [FN480] Rather, the discourse might serve to create*76 an atmosphere that nurtures productive dialogue on both "practical and conceptual matters that will propel feminism as it takes its next steps in ... Africa." [FN481]

While they likely did not seek to take the lead in the ideological inquiry, the members of the Victoria Mxenge Housing and Development Association have as a practical matter entered this dialogue, extending the traditional African concept of woman as homemaker and mother in a fashion that expands their influence in the familial as well as the societal spheres. [FN482] The experience of these women with their largely self-created built environment reflects their new and active engagement with the shifting social, economic, and political environment in post-apartheid South Africa. The members of the Association organized themselves and secured a role in the evolution of the nation. 
This localized engagement parallels the move in development and feminist theory and practice that focuses on the "local" as the principal site for socio-economic and democratic development. [FN483] The building project empowered the Victoria Mxenge members to "participate in the complicated process of turning de jure rights to adequate shelter into de facto rights[,]" and this participation influenced the formulation of official state housing policy in ways that benefit other impoverished citizens seeking housing in an increasingly urbanized South Africa. [FN484]

Law and legal rights thus remain important tools for achieving not only societal goals, but also for fulfilling those goals of the individual, particularly when used in conjunction with other strategies. [FN485] Implementation of the constitutional right to adequate shelter remains a fundamental challenge for the South African government, but the Victoria Mxenge Housing Association and similar groups have forged a space in which to transform formal legal concepts into brick-and-mortar housing and have opened the way for official consideration of alternative policies and paradigms on housing.

Engaging, co-opting, and implementing the legal programs and socio-economic resources available to them, Association members conceived of and constructed "homes" on their own terms--terms which they defined themselves. Members not only actively constructed a place of abode, they also forged a place within which to actualize their citizenship and to engage with the civil, political, and economic life of the nation. Home construction was thus a means of personal and community, as well as residential, development. Through this work, these African women framed a very personal, practical, and powerful feminism.

While this very individualized conception of feminism may not fit neatly $* 77$ into an existing label in the "expanding taxonomy of positioned interpretations of [African] women's experience," [FN486] it eschews rhetoric or discourse and accommodates the specific material conditions in which Association members subsisted. [FN487] It is representative of the "praxial" response of traditional African women to their "triple oppression" and distills the very essence of feminist ideals. Perhaps it merits its own label, "Women Independent of Naming," an appropriate name to celebrate the success of the exceptional women of the Victoria Mxenge Housing Association.

Exploring the theoretical polyphony and ambiguity in global feminist pedagogy in the context of an African indigenization project [FN488] is intellectually stimulating and discursively valuable. Ultimately, however, what matters is not that one attaches to it the label "feminism," "womanism," "stiwanism," or "nego-feminism," but that the project has a positive impact upon the quality of life of the women so labeled.

[FNd1]. Associate Professor of Law, University of Tennessee College of Law. Email: jacobs@utk.edu. In addition to honoring the remarkable members of the Victoria Mxenge Housing and Development Association, this Article also is dedicated to the brave South African women who risked their lives to participate in the historic Women's March on August 9, 1956, the fiftieth anniversary of which was celebrated in 2006. This event is marked annually in the country as National Women's Day. The author would like to thank Professor Penelope Andrews, CUNY's Associate Dean for Academic Affairs, for her erudite and insightful review and comments. Professor Andrews' suggestions improved this article enormously, as did the incredible work of the talented editors of the Berkeley Journal of Gender, Law \& Justice.

[FN1]. This reference to "African" women reflects the clumsiness of generalizations inherent in discussions of theoretical approaches in the context of a global discourse. This reference is one of convenience and certainly is not intended to in any way deny or diminish the rich ethnic, racial, social, cultural, geographical, political, religious, or economic diversity of women associated in some way with the African continent. 
[FN2]. Gwendolyn Mikell, Introduction to African Feminism: The Politics of Survival in Sub-Saharan Africa 1, 1 (Gwendolyn Mikell ed., 1997).

[FN3]. To honor and preserve the original dialogue and the theoretical constructs and ideals of the feminist theorists participating in this dialogue, this author quotes and paraphrases extensively, making every effort to provide appropriate context and attribution. The literature is rich and erudite, and any errors stem from the author's own observational enthusiasm.

[FN4]. Obioma Nnaemeka, Nego-Feminism: Theorizing, Practicing, and Pruning Africa's Way, 29 Signs: J. Women in Culture \& Soc'y 357, 378 (2003).

[FN5]. For those interested in a detailed study of this debate, there are a number of fascinating conferences and publications. See, e.g., Susan Arndt, The Dynamics of African Feminism: Defining and Classifying African Feminist Literatures (Isabel Cole trans., 2002); Mikell, supra note 2; South African Feminisms: Writing, Theory, and Criticism, 1990-1994 (M.J. Daymond ed., 1996); 2 Current Writing: Text \& Reception in S. Afr. 1, 1-70 (1990).

[FN6]. See Fareda Banda, Global Standards: Local Values, 17 Int'l J.L. Pol'y \& Fam. 1, 14-15 (2003).

[FN7]. Id.

[FN8]. See bell hooks, Ain't I A Woman: Black Women and Feminism (1981); bell hooks, The Politics of Radical Black Subjectivity, in Yearning: Race, Gender, and Cultural Politics 15, 15-22 (1990); and bell hooks, Feminist Theory: From Margin to Center (1984), for examples of her criticisms of northern-based or liberal feminism. The lower case spelling of her pseudonym reflects hooks's own preference for emphasizing the substance of her work. See bell hooks, Berea College, http:// www.berea.edu/appalachiancenter/people/bellhooks.asp (last visited Nov. 5, 2010). For a complete bibliography of bell hooks's works, see id.

[FN9]. Banda, supra note 6, at 15.

[FN10]. Cecily Lockett, Feminism(s) and Writing in English in South Africa, in South African Feminisms, supra note 5, at $11-12$.

[FN11]. Id. at 5.

[FN12]. See generally Alice A. Jardine, Gynesis: Configurations of Woman and Modernity (1985). In her book, Jardine explores the often-antagonistic debate that separates American feminists and French women theorists. Charles J. Stivale, 59 French Rev. 967 (1986) (reviewing Jardine, supra). Jardine proposes a Franco-American feminist dialogue that examines how the metaphorized concept of "the 'feminine' as cultural and libidinal constructions" appears in the important configurations of "modernity." Id. (quoting Jardine, supra, at 37).

[FN13]. Jardine, supra note 12, at 41 (emphasis omitted).

[FN14]. See, e.g., Arndt, supra note 5, at 32-33.

[FN15]. See, e.g., Lockett, supra note 10, at 7.

[FN16]. Id. at 6.

[FN17]. Id. 
[FN18]. Peter Waterman, Feminism, Globalisation and Internationalism: The State of Play and Direction of the Movement, Rev. Int'1 Soc. Questions (Mar. 19, 2005), http://www.risq.org/modules.php?name=News\&file=print\&sid=435.

[FN19]. Lockett, supra note 10, at 7. See also Jill Arnott, French Feminism in a South African Frame?, in South African Feminisms, supra note 5, at 77 (noting the persistence of a widespread perception that French feminism, as an abstract, elitist theory, was ill-suited to address the practical problems of South African feminists).

[FN20]. See Lockett, supra note 10, at 6; Banda, supra note 6, at 15.

[FN21]. Arndt, supra note 5, at 11.

[FN22]. Lockett, supra note 10, at 15.

[FN23]. See Banda, supra note 6, at 15.

[FN24]. See id., at 14-15.

[FN25]. Cf. Lockett, supra note 10, at 16 (quoting Dabi Nkululeko, The Right to Self-Determination in Research: Azanian Women, in Women in Southern Africa (Christine N. Qunta ed., 1987)).

[FN26]. Banda, supra note 6 , at 15 .

[FN27]. Arndt, supra note 5, at 34 (emphasis omitted).

[FN28]. Id.

[FN29]. See Banda, supra note 6, at 16 (citing Southern African Development Community, Declarations on Gender and Development 20 (1997)).

[FN30]. Arndt, supra note 5, at 23.

[FN31]. See id. at 71-72. Cf. M.J. Daymond, Introduction to South African Feminisms, supra note 5, at xxxviii ("This reason for heeding the work of presently marginalized women is a counterpart to our need in South Africa to indigenize theory[.]"). This indigenization project is not limited to the African continent. See, e.g., Sue N. Greene, Report on the Third International Caribbean Women Writers Conference, 16 Callaloo 65, 68 (1993) (discussing the conference's panel on "Multi-Cultural Prism and the Indigenizing Process").

[FN32]. See Banda, supra note 6, at 15.

[FN33]. Arndt, supra note 5, at 27. Arndt notes, however, that many anti-feminist reactions stem from stereotypical notions of feminism that equate all feminism with radical feminism. Id.

[FN34]. Id.

[FN35]. See Daymond, supra note 31, at xxvii.

[FN36]. See id.

[FN37]. Arndt, supra note 5, at 44 (quoting Zoë Wicomb, To Hear the Variety of Discourses, in South African Feminisms, supra note 5, at 47). 
[FN38]. Desiree Lewis, The Politics of Feminism in South Africa, in South African Feminisms, supra note 5, at 98.

[FN39]. Wicomb, supra note 37, at 49.

[FN40]. Cf. id. ("[W]hite feminists, ... identified the traditional place of female veneration--the home, motherhood, the family - as the very site of their oppression[.]")

[FN41]. Lewis, supra note 38.

[FN42]. Cf. Lourdes Benería \& Gita Sen, Class and Gender Inequalities and Women's Role in Economic Development: Theoretical and Practical Implications, 8 Feminist Stud. 157, 169-70 (1982). The authors argue that developmental theories ignore the impact of class processes on the specific causes of women's subordination and that integration of women into waged employment does not relieve the inimical effects of their gender and class. Id.

[FN43]. Zoë Wicomb, supra note 37, at 47.

[FN44]. Zillah Eisenstein, Against Empire: Feminisms, Racism, and "The" West (2004), as reprinted in, What's in a Name?: Seeing Feminism, Universalism, and Modernity, 1 Wagudu 1, 15 (2004), available at http:// appweb.cortland.edu/ojs/index.php/Wagadu/article/viewFile/376/715.

[FN45]. Lockett, supra note 10, at 18 (quoting Judy Kimble \& Elaine Unterhalter, We Opened the Road For You, You Must Now Go Forward: ANC Women's Struggles, 1912-1982, 12 Feminist Rev. 11, 12 (1982)).

[FN46]. Lewis, supra note 38, at 102.

[FN47]. See Daymond, Preface to 2 Current Writing: Text \& Reception in S. Afr. i (1990).

[FN48]. See, e.g., Wicomb, supra note 37, at 48.

[FN49]. See generally Alice Walker, In Search of Our Mothers' Gardens: Womanist Prose (1983).

[FN50]. The Reader's Companion to U.S. Women's History 640 (Wilma Mankiller et al. eds., 1998).

[FN51]. Id.

[FN52]. Clenora Hudson-Weems, Africana Womanism: Reclaiming Ourselves 58 (1993).

[FN53]. Faculty Profile: Dr. Clenora Hudson-Weems, U. Mo.-Columbia, http:// web.missouri.edu/ hudsonweemsc (last visited Sept. 22, 2010) (providing an abstract of Africana Womanism: Reclaiming ourselves, supra note 52).

[FN54]. See Arndt, supra note 5, at 43 (quoting Chikwenye Okonjo Ogunyemi, Africa Wo/Man Palava: The Nigerian Novel by Women 114 (1996)).

[FN55]. Id. at 42.

[FN56]. Id. at 39.

[FN57]. Mary E. Modupe Kolawole, Womanism and African Consciousness 24 (1997).

[FN58]. Id; see also Arndt, supra note 5, at 51 (discussing Modupe Kolawole's book). 
[FN59]. See generally Kolawole, supra note 57.

[FN60]. Molara Ogundipe-Leslie, Re-Creating Ourselves: African Women \& Critical Transformations 229 (1994).

[FN61]. See id. at 230; Arndt, supra note 5, at 50.

[FN62]. Nnaemeka, supra note 4, at 360-61.

[FN63]. Elvira Godono, Postcolonial Motherism: A Brand New Woman in the African Novel, Contemp. Postcolonial \& Postimperial Literature Eng., http:// www.postcolonialweb.org/africa/godona1.html (last visited Oct. 27, 2010) (quoting Catherine Obianuju Acholonu, Motherism: The Afrocentric Alternative, Konch Mag. (2008)).

[FN64]. Toni Morrison, Beloved 190 (1987).

[FN65]. Arndt, supra note 5, at 64.

[FN66]. See, e.g., Lockett, supra note 10, at 6.

[FN67]. Banda, supra note 6, at 15.

[FN68]. Arndt, supra note 5, at 33.

[FN69]. Mikell, supra note 2, at 1.

[FN70]. Id. at 1-2.

[FN71]. Daymond, supra note 31, at xlvii.

[FN72]. See Lockett, supra note 10, at 6.

[FN73]. Daymond, supra note 31, at xlviii; see also Emily R. Zinn, Rediscovery of the Magical: On Fairy Tales, Feminism, and the New South Africa, 46 Mod. Fiction Stud. 246 (2000) (noting that Gordimer denies any association with feminism).

[FN74]. Wicomb, supra note 37, at 50 (quoting Chikwenye Okonjo Ogunyemi).

[FN75]. Arndt, supra note 5, at 34.

[FN76]. Arnott, supra note 19, at 87.

[FN77]. See Lockett, supra note 10, at 14.

[FN78]. See Lewis, supra note 38, at 96.

[FN79]. Cf. Banda, supra note 6, at 13 ("The lives of urbanized professional women are not representative of the lives of most women in Africa and yet it is this group which is at the forefront of asking the 'woman question' and suggesting solutions to it.").

[FN80]. A meaningful discussion of these analytical models is beyond the scope of this article. For an introduction to this field, see Shahrashoub Razavi \& Carol Miller, From WID to GAD: Conceptual Shifts in the Women and Development 
Discourse (U.N. Research Inst. for Soc. Dev. Occasional Paper No. 1, 1995), available at http:// www.unrisd.org/unrisd/website/document.nsf/0/d9c3fca78d3db32e80256b67005b6ab5/ \$FILE/opb1.pdf.

[FN81]. Ester Boserup, Woman's Role in Economic Development (1970).

[FN82]. Javier Pereira Bruno, Feminist Approaches to Development and the Critique to Western Feminist Paradigms 5 (Jan. 2006) (unpublished manuscript, Univ. of Texas at Austin), available at http://www.allacademic.com//meta/p_mla_ apa_research_citation/1/0/3/3/3/pages103333/p103333-1.php.

[FN83]. See, e.g., Feminist Visions of Development: Gender Analysis and Policy 1 (Cecile Jackson \& Ruth Pearson eds. 1998) (emphasis removed).

[FN84]. Daymond, supra note 31, at xvii.

[FN85]. Arndt, supra note 5, at 33.

[FN86]. Id. at 30.

[FN87]. Id. at 30-31.

[FN88]. Id. at 30-31 (quoting Ogunyemi supra note 54, at 27).

[FN89]. Obioma Nnaemeka, Introduction to Sisterhood, Feminisms and Power: From Africa to the Diaspora 1, 5 (Obioma Nnaemeka ed., 1998) (quotation and citation omitted).

[FN90]. See Obioma Nnaemeka, This Women's Studies Business: Beyond Politics and History, in Sisterhood, Feminisms \& Power, supra note 89 , at 351, 379-81.

[FN91]. Arndt, supra note 5, at 28.

[FN92]. Arnott, supra note 19, at 97-98.

[FN93]. Id. at 97.

[FN94]. See generally Mark Mathabane, African Women: Three Generations (1994). This book narrates an inspiring account of the life of one such remarkable family of South African women who suffer not only under the yoke of apartheid, but also at the hands of the men they love. Yet, their strength of will, patience, faith, and indomitable spirits sustain them. Id.

[FN95]. See Arndt, supra note 5, at 34.

[FN96]. See Mikell, supra note 2, at 33.

[FN97]. See generally Rachel Rebouché, Labor, Land, and Women's Rights in Africa: Challenges for the New Protocol on the Rights of Women, 19 Harv. Hum. Rts. J. 235 (2006) (discussing the status of African women's rights in the context of the 2003 Additional Protocol to the African Charter on Human and People's Rights).

[FN98]. See Mikell, supra note 2, at 28.

[FN99]. For purposes of this discussion, the term "historical" refers to both pre- and post-colonial periods, with an ac- 
knowledgement of the legacy of the colonial era that persists in the present.

[FN100]. Cf. Women's Rights Project, Legal Resources Centre 4 (2004), available at http://www.lrc.org.za/Docs/Papers/WPN\%20publication.pdf.

[FN101]. See Mikell, supra note 2, at 3.

[FN102]. In this context, "customary law" refers to the law derived from obligatory social practices in particular indigenous communities. See, e.g., TW Bennett, Customary Law in South Africa 1 (2004).

[FN103]. Women's Rights Project, supra note 100, at 26.

[FN104]. Id. at 27, 33.

[FN105]. Hilda Bernstein, For Their Triumphs \& For Their Tears: Women in Apartheid South Africa (3d ed. 1985).

[FN106]. Women's Rights Project, supra note 100, at 26.

[FN107]. Id. at 27.

[FN108]. Id. at 33.

[FN109]. Questions regarding the equitable distribution or division of property amongst multiple wives upon the death of the husband or when a marriage is dissolved can become complicated. See Adriana Stuijt, Polygamy Becomes a Hot Election Issue in South Africa, Digital J. (Apr. 11, 2009), http://www.digitaljournal.com/article/270793; see also Karrisha Pillay et al., Inst. for Democracy in S. Afr., Budget Brief No. 111, The Grootboom Case and Women's Housing Rights 4 (2002), available at http:// www.idasa.org.za/gbOutputFiles.asp?WriteContent=Y\&RID=655.

[FN110]. See Sharita Samuel, Women Married in Customary Law: No Longer Permanent Minors, 40 Agenda 23 (1999); S. Afr. Law Comm'n, Issue Paper 3, Project 90, Harmonisation of the Common Law and the Indigenous Law (Customary Marriages) (October 1996), available at http:// www.saflii.org/za/other/zalc/ip/3/.

[FN111]. David L. Chambers, Civilizing the Natives: Marriage in Post-Apartheid South Africa, 129 Daedalus 101,104 (2000).

[FN112]. See Women's Rights Project, supra note 100, at 35.

[FN113]. Id.

[FN114]. See Pillay et al., supra note 109, at 4.

[FN115]. Celina Romany, Black Women and Gender Equality in a New South Africa: Human Rights Law and the Intersection of Race and Gender, 21 Brook. J. Int'l L. 857, 865 (1996).

[FN116]. See Choice of Future Legal System: Lisa Fishbayn Calls for the Integration of Customary and Civil Law in Line with the Constitution, Gender Res. Project Bull. (Ctr. for Applied Legal Studies, Johannesburg, S. Afr.), 1997, at 3 (on file with author).

[FN117]. Id. 
[FN118]. See id.

[FN119]. See generally Martin Chanock, Neither Customary Nor Legal: African Customary Law in an Era of Family Law Reform, 3 Int'l J. L. \& Fam. 72 (1989) (reflecting upon the wisdom of relying upon or adopting customary law in the context of the family law reform given its fractured and non-linear history and the influence of colonial/western influence on the development thereof).

[FN120]. See generally René de Villiers, Afrikaner Nationalism, in 2 The Oxford History of South Africa 365, 371-74 (Monica Wilson \& Leonard Thompson eds., 1971) (discussing the influences of neo-Calvinism on Afrikaner (South African of Dutch ancestry) nationalism); Penelope E. Andrews, From Gender Apartheid to Non-Sexism: The Pursuit of Women's Rights in South Africa, 26 N.C. J. Int'1 L. \& Com. Reg. 693, 697-98 (2001) [hereinafter Andrews, From Gender Apartheid to Non-Sexism].

[FN121]. Andrews, From Gender Apartheid to Non-Sexism, supra note 120, at 695, 695 n.14. Women among the segment of South Africa's Muslim population adhering to Islamic law, particularly the Islamic personal law, suffered additional discriminatory impacts. See, e.g., S. Afr. Law Reform Comm'n, Report on Islamic Marriages and Related Matters 1 n.1 (2003), available at http:// www.doj.gov.za/salrc/reports/r_prj59_2003jul.pdf.

[FN122]. Penelope E. Andrews, Striking the Rock: Confronting Gender Equality in South Africa, 3 Mich. J. Race \& L. 307, 309 (1998).

[FN123]. Population Registration Act 30 of 1950 (repealed 1991). A "native" person is one who is a member of any aboriginal race or tribe of Africa. Id. Thus, this category is often referred to as "black." De Villiers, supra note 120, at 402. This category was later changed to Bantu, an apartheid-era derogatory term referring to black Africans who did not speak Khoisan languages. Albie Sachs, Enforcement of Social and Economic Rights, 22 Am. U. Int'l L. Rev. 673, 704 n.105 (2007). These racial categories were then subdivided into sub-groups. Carol M. Kaplan, Gender and Justice in Africa: Voices Rising: An Essay on Gender, Justice and Theater in South Africa, 3 Seattle J. Soc. Just. 711 n.2 (2005). In 1959, the category "Asian" was added to the classification system. Id. This category referred to "Indians who had, prior to that time, not been recognized as permanent citizens of South Africa." Id.

[FN124]. See De Villiers, supra note 120, at 409-13 (discussing various laws that limited or denied civil and political rights to South Africans based upon their racial classifications).

[FN125]. Andrews, From Gender Apartheid to Non-Sexism, supra note 120, at 695, 722 n.14.

[FN126]. Id. at 695-96.

[FN127]. Native (Urban Areas) Consolidation Act 25 of 1945 (repealed by Abolition of Influx Control Act 68 of 1986). This Act superseded a similar law, the Native (Black) Urban Areas Act 21 of 1923.

[FN128]. Bentley J. Anderson, The Restoration of the South African Citizenship Act: An Exercise in Statutory Obfuscation, 9 Conn. J. Int'l L. 295, 310 n.79 (1994) (quoting T.R.H. Davenport, South Africa: A Modern History 235-36 (4th ed. 1991)).

[FN129]. Pass laws refer to the various influx control regulations passed during apartheid. See, e.g., Anderson, supra note 128, at 309-10. These laws required all Africans to carry and present upon demand a "pass book," akin to an internal passport, that contained identifying data, including, for example, their photograph, fingerprints, employment information, and the geographical areas to which they were permitted entry. Id. 
[FN130]. See Leonard Thompson, A History of South Africa 193 (1990).

[FN131]. See Andrews, From Gender Apartheid to Non-Sexism, supra note 120, at 696.

[FN132]. See Rebekah Lee, Reconstructing 'Home' in Apartheid Cape Town: African Women and the Process of Settlement, 31 J. S. Afr. Stud. 611, 616 (2005).

[FN133]. See Native Laws Amendment Act 54 of 1952 s. 27 (amending Native (Urban Areas) Consolidation Act 23 of 1945 s. 10). Under the Act, only Africans with Section 10 rights legally could reside in a designated Urban Area, and rights would be granted in only three situations: Section 10 (1)(a) granted residence rights if a person had continuously resided in the urban area in question since birth; Section 10 (1)(b) granted residence rights if the person had lived continuously in the urban area for fifteen years or had worked for the same employer for ten years; and Section 10 (1)(c) allowed residence rights to be acquired by dependants of someone with Section 10 (1)(a) or (b) rights. Lee, supra note 132, at 616 n.16. Africans who did not meet these specifications were required to obtain a permit to search for work. Id.

[FN134]. See Lee, supra note 132, at 616.

[FN135]. Id. at 615-16.

[FN136]. Id. at 616.

[FN137]. Id.

[FN138]. Id.

[FN139]. Id.

[FN140]. Id.

[FN141]. Id.

[FN142]. Id.

[FN143]. Id .at 617.

[FN144]. Id. at 616-17.

[FN145]. Id.

[FN146]. Andrews, From Gender Apartheid to Non-Sexism, supra note 120, at 695.

[FN147]. Id.

[FN148]. Id. (quoting Albie Sachs, Judges and Gender: The Constitutional Rights of Women in a Post-Apartheid South Africa, 7 Agenda 1 (1990)).

[FN149]. See, e.g., Daymond, supra note 31, at xxviii.

[FN150]. See id. 
[FN151]. Suzanne A. Kim, Betraying Women in the Name of Revolution: Violence Against Women as an Obstacle to Democratic Nation-Building in South Africa, 8 Cardozo Women's L.J. 1, 13 (2001).

[FN152]. Daymond, supra note 31, at xxviii.

[FN153]. See Kim, supra note 151, at 13-14.

[FN154]. Woman's Charter, Adopted at the Founding Conference of the Federation of South African Women, Johannesburg (Apr. 17, 1954), available http://www.sahistory.org.za/pages/governence-projects/womens-struggle/struggle5_3.htm; see also Kim, supra note 151, at 13-14 (noting that the Charter did not adequately address inequality because it "adhered to the limited role of women as wives and mothers" and subordinates gender equality to national liberation).

[FN155]. Andrews, From Gender Apartheid to Non-Sexism, supra note 120, at 717.

[FN156]. The anniversary of the Women's March is celebrated on August 9. See Public Holidays, S. Afr. Gov't info., http:// www.info.gov.za/aboutsa/holidays.htm (last modified Sept. 27, 2010).

[FN157]. Andrews, From Gender Apartheid to Non-Sexism, supra note 120, at 717.

[FN158]. See Kim, supra note 151, at 14-15 (discussing the preference of racial equality discourse instead of, and at the expense of, gender equality during the constitutional negotiations of the 1990s).

[FN159]. Id. at 14.

[FN160]. Id. (citing the ANC's Constitutional Guidelines for a Democratic South Africa (1988)).

[FN161]. Id. at 14-15.

[FN162]. Justice Yvonne Mokgoro, Constitutional Claims for Gender Equality in South Africa: A Judicial Response, 67 Alb. L. Rev. 565, 566 (2003).

[FN163]. Kim, supra note 151, at 5. The efforts of the Federation of African Women similarly focused on the "issue of gender discrimination and its prevalence in customary law." Christine Mary Venter, The New South African Constitution: Facing the Challenges of Women's Rights and Cultural Rights in Post-Apartheid South Africa, 21 J. Legis. 1, 7 (1995).

[FN164]. See Kim, supra note 151, at 5.

[FN165]. Id.

[FN166]. Women's Nat'l Coalition of S. Afr., Women's Charter for Effective Equality (1994), available at http://www.anc.org.za/233 (second draft version). The preamble to the Charter stated that "[w]e set out here a programme for equality in all spheres of our lives, including the law, the economy, education, development and infrastructure, political and civic life, family life and partnerships, custom, culture and religion, health and the media." Id. at pmbl.

[FN167]. Article 2 of the Charter stated that "[w]omen shall have equal legal status and capacity in civil law, including, amongst others, full contractual rights, the right to acquire and hold rights in property, the right to equal inheritance and the right to secure credit." Id. at art. 2. Article 5 of the Charter provided that "[w]omen must have equal access to land 
and security of tenure, including women living under customary law." Id. at art. 5. Article 8 of the Charter provided that "[w]omen married under customary law shall have the right to inherit from their husbands." Id. at art. 8.

[FN168]. Article 2 of the Charter provided that "[w]omen shall have equal representation on, and participation in all traditional courts, alternative dispute resolution mechanisms and local community courts." Id. at art. 2. Similarly, Article 7 stated that "[r]ural women have the right to be part of decision-making structures in traditional communities." Id. at art. 7. Article 7 of the Charter also provided that "[t]raditional institutions shall be restructured in accordance with the principles of equality and democracy." Id.

[FN169]. See id. at art. 8.

[FN170]. Id. at art. 9.

[FN171]. See Kim, supra note 151, at 15.

[FN172]. Andrews, Striking the Rock, supra note 122, at 322.

[FN173]. See Kim, supra note 151, at 15.

[FN174]. Andrews, Striking the Rock, supra note 122, at 321-22.

[FN175]. Kim, supra note 151, at 15.

[FN176]. Id. at 6.

[FN177]. Id.

[FN178]. Andrews, Striking the Rock, supra note 122, at 323-24.

[FN179]. See id. See also Valorie K. Vojdik, Conceptualizing Intimate Violence and Gender Equality: A Comparative Approach, 31 Fordham Int'l L.J. 487, 513 (2008).

[FN180]. Kim, supra note 151, at 3.

[FN181]. See generally South Africa: Women's Representation in the National Assembly, available at http://www.eisa.org.za/WEP/souwomenrepresent.htm; see also S. Afr. Gov't Online, http://www.gov.za (providing for more information about the national government of South Africa).

[FN182]. See Kim, supra note 151, at 15.

[FN183]. This article focuses on South African law as it pertains to women's rights and does not address how regional agreements or international legal instruments might impact this analysis. Such analysis is beyond the scope of this article. The author hopes to explore these themes, and particularly to examine South Africa's progress vis-à-vis the United Nations Millennium Development Goals, in a future project.

[FN184]. Andrews, From Gender Apartheid to Non-Sexism, supra note 120, at 718.

[FN185]. Kim, supra note 151, at 1.

[FN186]. S. Afr. Const. 1996. ch. I, §§ 1(a), (b). 
[FN187]. S. Afr. Const. 1996. ch. II, § 9(3).

[FN188]. S. Afr. Const. 1996. ch. II, § 9(1).

[FN189]. S. Afr. Const. 1996. ch. II, § 9(3).

[FN190]. S. Afr. Const. 1996. ch. II, § 9(4).

[FN191]. S. Afr. Const. 1996. ch. II, § 9(4).

[FN192]. S. Afr. Const. 1996. ch. II, § 9(5). Some have argued that the scope of the relevant constitutional provisions is limited by the constitutional recognition of customary law and institutions. See, e.g., Kim, supra note 151, at 15.

[FN193]. See Andrews, Striking the Rock, supra note 122, at 333-34.

[FN194]. Id. at 334 (quoting S. Afr. Const. 1996. ch. II, § 30).

[FN195]. Id. (quoting S. Afr. Const. 1996. ch. II, § 31). Further, while the Bill of Rights makes provision for legislation that recognizes marriages concluded under any traditional or customary system, it demands that these systems be consistent with the Constitution's principle of equality. Id. (citing S. Afr. Const. 1996. ch. II, § 15).

[FN196]. Id. at 334-35 (citing S. Afr. Const. 1996. ch. II, § 39(2)).

[FN197]. S. Afr. Const. 1996. ch. XII, § 211(3).

[FN198]. Andrews, Striking the Rock, supra note 122, at 334.

[FN199]. S. Afr. Const. 1996. ch. IX, § 187(1).

[FN200]. S. Afr. Const. 1996. ch. IX, § 187(2).

[FN201]. Andrews, From Gender Apartheid to Non-Sexism, supra note 120, at 718.

[FN202]. Kim, supra note 151, at 20 (quoting Catherine Albertyn, Women and the Transition to Democracy in South Africa, in Gender and the New South African Legal Order 46 (Christina Murray ed., 1994)).

[FN203]. See Kim, supra note 151, at 6-7.

[FN204]. See id. at 6.

[FN205]. See, e.g., Penelope Andrews, Evaluating the Progress of Women's Rights on the Fifth Anniversary of the South African Constitution, 26 Vt. L. Rev. 829, 835 (2002).

[FN206]. Cf. Kim, supra note 151, at 20 (stating that "[w]omen's rise to political power and the apparent national commitment to gender equality contrast starkly with the social reality of many women's lives ....”).

[FN207]. Pillay et al., supra note 109, at 3.

[FN208]. Id. 
[FN209]. See Beneria \& Sen, supra note 42, at 170.

[FN210]. Arndt, supra note 5, at 29.

[FN211]. Id.

[FN212]. See Wicomb, supra note 37 at 50.

[FN213]. Pillay et al., supra note 109, at 3.

[FN214]. See Arndt, supra note 5, at 29.

[FN215]. Andrews, From Gender Apartheid to Non-Sexism, supra note 120, at 720.

[FN216]. Adrien Katherine Wing \& Eunice P. de Carvalho, Black South African Women: Toward Equal Rights, 8 Harv. Hum. Rts. J. 57 (1995).

[FN217]. Housing and land reform remain a high profile part of the national discourse in South Africa. For a detailed account of cultural references to the topic, see Becky L. Jacobs, The Post-Apartheid City in the New South Africa: A Constitutional “Triomf”?, 18 Pace Int'l L. Rev. 407 (2006).

[FN218]. See S. Afr. Const. 1996. ch. II, §§ 25, 26.

[FN219]. For a thoughtful analysis of South Africa's nearly revolutionary Constitution, see Mark S. Kende, The South African Constitutional Court's Embrace of Socio-Economic Rights: A Comparative Perspective, 6 Chap. L. Rev. 137 (2003). Professor Kende concludes that "[t]he United States Supreme Court and American scholars could learn much from the South African Constitutional Court's socio-economic decisions.” Id. at 160.

[FN220]. S. Afr. Const. 1996. ch. II, § 25(5).

[FN221]. S. Afr. Const. 1996. ch. II, § 25(8).

[FN222]. S. Afr. Const. 1996. ch. II, § 26(1).

[FN223]. S. Afr. Const. 1996. ch. II, § 26(2).

[FN224]. S. Afr. Const. 1996. ch. II, § 25(2).

[FN225]. S. Afr. Const. 1996. ch. II, § 25(4)(a).

[FN226]. S. Afr. Const. 1996. ch. II, § 25(7). The June 19, 1913 date limitation is not without controversy. "[V]arious symbolically laden years-- 1948, 1913, 1652--[were proposed] as the most legitimate cutoff point for the history of land dispossession that the restitution program should cover; this issue continues to simmer in political debate today." Cherryl Walker, Misplaced Agrarianization? Reflections on Ten Years of Land Restitution, 72 Soc. Res. 647, 650 (2005), available at http:// Socialresearch.metapress.com/app/home/contribution.asp? referrer=parent\&backto=homemainpublications, 1,1 .

[FN227]. S. Afr. Const. 1996. ch. II, § 25(6).

[FN228]. See Lauren G. Robinson, Rationales for Rural Land Redistribution in South Africa, 23 Brook. J. Int'1 L. 465, 
487 (1997).

[FN229]. Responsibility for the implementation of housing and human settlement policy now resides with the Department of Human Settlement, a fairly new department created in 2009. See http://www.dhs.gov.za/. For an in-depth analysis of the administrative processes that were involved in South Africa's land reform efforts, see generally D. L. Carey Miller \& Anne Pope, Land Title in South Africa (2000).

[FN230]. Reconstruction and Development Programme Fund Act 7 of 1994 [hereinafter RDP]. The RDP is a policy framework document adopted shortly after the ANC came to power in 1994 that sets forth the principles that were to guide the new government's action. Hereinafter, except as expressed in quotations, the more typical U.S. spelling will be used for the word "Program."

[FN231]. See Heather Boyle, Note, The Land Problem: What Does the Future Hold for South Africa's Land Reform Program?, 11 Ind. Int'l \& Comp. L. Rev. 665, 674 n.81 (2001).

[FN232]. S. Afr. Dep't of Land Affairs, Our Land: Green Paper on South African Land Policy (1996) [hereinafter Green Paper].

[FN233]. Id. at ii.

[FN234]. Id. at i-ii.

[FN235]. See Andre J. Groenewald, South Africa's Land Reform Programme, 5 Scholar 195, 195-98 (2003).

[FN236]. The term "previously disadvantaged person (or individual)" was intended to encompass all victims of apartheid, and, in practice, "eligibility for redistribution requires only that one [be] a black South African." Michael Aliber, What Went Wrong? A Perspective on the First Five Years of Land Redistribution in South Africa, with Homily for the Next Five, Oxfam, June 2003, at 8, http://www.oxfam.org.uk/what_we_ do/issues/livelihoods/landrights/downloads/wrongsa.rtf.

[FN237]. There are five stages to a typical redistribution project: (1) Making an Application, (2) Planning for Settlement, (3) Approval and Land Transfer, (4) Detailed Planning and Implementation, and (5) Development and Support. Boyle, supra note 231, at $680 \mathrm{n} .127$. Redistribution of land is ranked according to the "most critical and desperate needs," with the marginalized and women also receiving priority. Id. (citing Green Paper, supra note 232, at 28).

[FN238]. See Provision of Land and Assistance Act 126 of 1993 pmbl.

[FN239]. Development Facilitation Act 67 of 1995.

[FN240]. Id. at pmbl.

[FN241]. See Green Paper, supra note 232, at 4.

[FN242]. S. Afr. President Thabo Mbeki, State of the Nation Address at the Joint Sitting of the Parliament (Feb. 3, 2006) (transcript available at http:// www.info.gov.za/speeches/2006/06020310531001.htm).

[FN243]. See Groenewald, supra note 235, at 197. But cf. Boyle, supra note 231, at 683-84 (discussing the major criticisms of the land reform program, notably its slow pace of delivery and complexity). 
[FN244]. See Groenewald, supra note 235, at 199.

[FN245]. Id.

[FN246]. Hasani Claxton, Note, Land and Liberation: Lessons for the Creation of Effective Land Reform Policy in South Africa, 8 Mich. J. Race \& L. 529, 547 (2003).

[FN247]. See Lauren Royston, Urban Tenure Reform in South Africa: Social Redress, Sustainable Development or Both?, UN Hum. Settlements Programme, tp://ww2.unhabitat.org/mdg/documents/africa/Vol5_No3_urban_tenure_reform.doc (last visited Sept. 22, 2010).

[FN248]. Interim Protection of Informal Land Rights Act 31 of 1996. This Act was passed to secure the rights of individuals with "informal" land rights, primarily in the former homeland areas, while more comprehensive legislation was being prepared. Id.

[FN249]. Land Reform (Labour Tenants) Act 3 of 1996.

[FN250]. The Extension of Security of Tenure Act 62 of 1997. Under this Act, tenure may only be terminated on lawful grounds, provided that any such termination is just and equitable, having regard to all relevant factors. Id. at s. 8(1). However, limited rights are accorded to the continued right of occupation of the spouse or dependants of the occupier. Id. at s. 8(5).

[FN251]. Prevention of Illegal Eviction from and Unlawful Occupation of Land Act 19 of 1998.

[FN252]. Communal Land Rights Act 11 of 2004.

[FN253]. In response to these laws, several areas created communal property associations and communal trusts to manage and allocate land. See Claxton, supra note 246, at 548. However, in its 1999 review, the South African Department of Land Affairs questioned the efficacy of such trusts. Id.

[FN254]. Prevention of Illegal Eviction from and Unlawful Occupation of Land Act 19 of 1998 s. 4(6).

[FN255]. See Royston, supra note 247, at 1.

[FN256]. Id. See S. Afr. Dep't of Hous., White Paper: A New Housing Policy and Strategy for South Africa $§ 3.2 .2$ (1994) [hereinafter White Paper]. The Constitutional Court of South Africa analyzed the right to housing in Government of the Republic of South Africa v. Grootboom 2001 (1) SA 46 (CC) (S. Afr.), a case that has been described as "[t]he seminal socio-economic rights case in South Africa." Kende, supra note 219, at 142. Mrs. Grootboom was part of a group of 390 adults and 510 children living in an informal settlement or shantytown known as Wallacedene, not far from Cape Town. Grootboom, 2001 (1) SA at $53 \&$ n.2. This settlement lacked running water, sewage, and garbage removal services, and only $5 \%$ of the shacks had electricity. Id. at 55 . To improve their circumstances, the group moved onto nearby vacant land, from which the group was evicted by its private owner. Id. When the group members could not return to their original settlement, they moved to a nearby municipal sports field and erected flimsy temporary structures that exposed them to winter rains and cold temperatures. Id. at 56. The group, dissatisfied with the government's response, obtained legal counsel and brought suit based upon the constitutional right of access to housing and the children's right to shelter. Id. (relying on S. Afr. Const. 1996. ch. II, §§ 26(2), 28(1)(c)). The country's Constitutional Court ruled for the settlers based upon the right to housing contained in Section 26 of the Constitution. Initially, the Court addressed whether socio-economic rights were justiciable, declaring that the budgetary implications of socio-economic rights do not bar 
their justiciability. Ruling on the merits, the court declined to determine whether the government is required to provide a "minimum core" level of housing, instead asking "whether the measures taken by the State to realise the right afforded by [Section] 26 are reasonable." Id. at 66 . The Court concluded: "To be reasonable, measures cannot leave out of account the degree and extent of the denial of the right they endeavour to realise.... If the measures ... fail to respond to the needs of those most desperate, they may not pass the test." Id. at 69. The Court declared that the government is obliged "to devise and implement within its available resources a comprehensive and coordinated programme progressively to realise the right of access to adequate housing." Id. at 87. According to the Court, this programme must include measures such as an accelerated land settlement programme to provide relief for people "who have no access to land, no roof over their heads, and who are living in intolerable conditions or crisis situations." Id. It went on to conclude that the housing scheme in the Cape Metropolitan area did not satisfy constitutional requirements as it failed to make reasonable provision for people in desperate need, but the Court did not compel the government to take any specific action to address this failure. Id. Thus, while the Court's holding forced compliance with the Constitution, it gave the government discretion on how to comply with the law. Id. For a more thorough analysis of the justiciability of social and economic rights generally, see Michael J. Dennis \& David P. Stewart, Justiciability of Economic, Social, and Cultural Rights: Should There Be an International Complaints Mechanism to Adjudicate the Rights to Food, Water, Housing, and Health?, 98 Am. J. Int'l L. 462 (2004); Mark Tushnet, Social Welfare Rights and the Forms of Judicial Review, 82 Tex. L. Rev. 1895 (2004); Gerald L. Neuman, Human Rights and Constitutional Rights: Harmony and Dissonance, 55 Stan. L. Rev. 1863 (2003).

[FN257]. S. Afr. Const. 1996. ch. II, § 26(1).

[FN258]. See Reconstruction and Development Programme Fund Act 7 of 1994.

[FN259]. The Reconstruction and Development Programme Fund Act set a goal of 300,000 houses to be built annually, with a minimum of one million low-cost houses to be constructed within five years. Id.

[FN260]. White Paper, supra note 256, § 1.

[FN261]. Id. § 4.2.

[FN262]. Housing Act 107 of 1997.

[FN263]. The Housing Act applies to all three branches of government in South Africa: national government, provincial government, and local government. See White Paper, supra note 256, § 5.2. A detailed elucidation of the function of each of these branches within the context of the Act is beyond the scope of this Article.

[FN264]. Housing Act 107 of 1997 s. 2(1)(c)(i).

[FN265]. Id. § 2(1)(d).

[FN266]. Id. § 4(1), amended by Housing Amendment Act 4 of $2001 \S 3(\mathrm{a})$.

[FN267]. Id. § 4; see also S. Afr. Dep't of Human Settlements, National Housing Code pt. 1 (2009), http://www.dhs.gov.za/ (follow "National Housing Code, 2009" hyperlink) [hereinafter National Housing Code]. The 2009 Housing Code substantially revised its 2000 predecessor with the intention of "simplifying the implementation of housing projects by being less prescriptive while providing clear guidelines." Id. at 10.

[FN268]. National Housing Code, supra note 267, at 9 . 
[FN269]. Id. (follow "National Housing Code, 2009" hyperlink to the "General Housing Subsidy Information" hyperlink; then follow the "Housing Subsidy Programmes" hyperlink).

[FN270]. Id., pt. 3, vol. 3, § 1 at 9 (follow "National Housing Code, 2009" hyperlink to the "Financial Interventions" hyperlink; then follow the "Individual Subsidy Programme" hyperlink).

[FN271]. Id. (follow "National Housing Code, 2009" hyperlink to the "General Housing Subsidy Information" link; then follow the "Housing Subsidy Amounts" link.) On September 22, 2010, the exchange rate for South African Rands (ZAR) to U.S. dollars was 1 ZAR $=0.142316$ USD. Therefore, 3,500 ZAR converts to approximately 498 USD. For the precise exchange rate, see http:// www.xe.com.

[FN272]. National Housing Code, supra note 267 (follow "National Housing Code, 2009" hyperlink to the "General Housing Subsidy Information" hyperlink; then follow the "Housing Subsidy Amounts" hyperlink.). Individual beneficiaries must satisfy a range of other related criteria, such as residency and competency. Id. at Part 1, Section 8.2.

[FN273]. Id. (follow "National Housing Code, 2009" hyperlink to the "General Housing Subsidy Information" hyperlink; then follow the "Housing Subsidy Amounts" hyperlink.) 84,000 ZAR converts to approximately 12,120 USD. For the precise exchange rate, see http://www.xe.com.

[FN274]. National Housing Code, supra note 267 (follow "National Housing Code, 2009" hyperlink to the "General Housing Subsidy Information" hyperlink; then follow the "Housing Subsidy Programmes" hyperlink). In order to address the lack of access to credit, the government proposed two legislative measures: the Community Reinvestment (Housing) Bill of 2002 and the Home Loan and Mortgage Disclosure Bill. The Community Reinvestment (Housing) Bill sought to provide minimum targets for financial institutions lending to low- and medium-income households for housing purposes. This bill apparently failed to be enacted. The Home Loan and Mortgage Disclosure Bill promoted fair lending practices by financial institutions, and it was passed as the Home Loan and Mortgage Disclosure Act 63 of 2000. See, e.g., Pillay et al., supra note 109 , at 9 . Access to finance is still of great concern to government housing officials. It is reported that approximately $70 \%$ of South African households are excluded from access to housing credit through the formal banking sector. See Background, S. Afr. Dep't of Human Settlements, http://www.dhs.gov.za (last visited Nov. 10, 2010) (follow "Housing Institutions" hyperlink). The Department of Human Settlements has adopted several initiatives to assist the under- and un-served portion of the population to increase lending from the formal banking sector to the lower end of the housing market, to foster growth and development of the emerging alternative lending sector, and to promote the mobilization of personal savings in the housing process. Id. A number of housing support institutions now exist to support these initiatives, including SERVCON, the Social Housing Foundation, the National Urban Reconstruction and Housing Agency, the National Home Builders Registration Council, the National Housing Finance Corporation, Thubelisha Homes, and the Rural Housing Loan Fund. Id. See also Annual Report 2008-2009, South African Dep't of Hous. 70-71, available at http://www.dhs.gov.za/Content/Documents/Annual\%20Report\% 202008-2009/Housing.pdf.

[FN275]. Marianne Millstein, Sophie Oldfield \& Kristian Stokke, uTshani BuyaKhuluma--The Grass Speaks: The Political Space and Capacity of the South African Homeless People's Federation, 34 Geoforum 457, 461 (2003).

[FN276]. Ted Baumann \& Diana Mitlin, The South African Homeless Peoples' Federation: Investing in the Poor, 14 Small Enterprise Dev. 32, 37 (2003).

[FN277]. Marie Huchzermeyer, Housing for the Poor? Negotiated Housing Policy in South Africa, 25 Habitat Int'l 303, 306 (2001). 
[FN278]. Baumann \& Mitlin, supra note 276, at 37.

[FN279]. In the 2009/2010 South Africa Yearbook, the government states that, by December 2008 it had built 2.8 million houses, providing free shelter for more than 13.5 million people. See S. Afr. Yearbook, 2009/2010 at 308, available at http://www.gcis.gov.za/resource_centre/sa_info/yearbook/2009-10/Human\%20Settlements.pdf. From 2004, the government's housing expenditure increased from 4.8 billion ZAR to 9 billion ZAR in 2007/08, representing an average growth of 23.2\% per year. See S. Afr. Yearbook, 2008/2009 at 332, available at http://www.gcis.gov.za/resource_centre/sa_ info/yearbook/2009/chapter13.pdf. Expenditure on housing service delivery increased by $23 \%$ to 10.9 billion ZAR in the 2008/09 financial year. See S. Afr. Yearbook, 2009/2010, at 308.

[FN280]. Baumann \& Mitlin, supra note 276, at 32 (noting how occupants immediately began to expand their small houses, "often replicating the shack construction of their previous homes").

[FN281]. Id.

[FN282]. Id.

[FN283]. Information about this initiative is available at http:// www.thehda.co.za/images/uploads/BREAKING_NEW_GROUND_DOC_copy-2_1.pdf.

[FN284]. Id. at 7.

[FN285]. Social Contract for Rapid Housing Delivery (Housing Indaba, Cape Town, Sept. 2005), available at http:// www.bullion.org.za/Departments/IRS/Downloads/Social\%20Contract\%C20for\%C20Rapid\%C20Housing\%D elivery.pdf. The government reports that the "banking sector has pledged more than R40 billion towards the provision of affordable mortgage products" and that the National Housing Finance Corporation has disbursed more than R2,4 billion in funding and delivered more than 264130 housing opportunities since 1996." See Human Settlements, S. Afr. Gov't Info., http:// www.info.gov.za/aboutsa/housing.htm\#legislationpolicyinitiatives (last modified Jul. 5, 2010).

[FN286]. Housing Development Agency Act 23 of 2008.

[FN287]. Id. at 7(2)(a).

[FN288]. National Housing Code, supra note 267, pt. 2, Section 3, at 15; Section 4.1.2.1, at 17 (follow "National Housing Code, 2009" hyperlink to the "Simplified Guide and Policy Context" hyperlink; then follow the "Policy Context" hyperlink).

[FN289]. See, e.g., Life: My Mother Built This House (TVE television broadcast May 16, 2003) (transcript available at http:// www.tve.org/lifeonline/index.cfm?aid=1116). This City Life Series documentary chronicles the Victoria Mxenge Housing and Development Association's housing project. Id. There also is a video posted on YouTube about the Association. See Journeyman Pictures, My Mother Built This House - South Africa, Youtube (Jan. 5, 2008), http://www.youtube.com/watch?v=zpTO5q93Edg.

[FN290]. See Life: My Mother Built This House, supra note 289.

[FN291]. Pillay et al., supra note 109, at 8.

[FN292]. Cf. Benería \& Sen, supra note 42, at 170 (discussing Ethiopia's "egalitarian" land reforms of the 1970s to 
demonstrate how rhetorical equality fails to provide women equal access when the state continues to distribute resources based on a patriarchal family structure).

[FN293]. Rental Housing Act 50 of 1999, amended by Rental Housing Amendment Act 43 of 2007.

[FN294]. See id.

[FN295]. Life: My Mother Built This House, supra note 289.

[FN296]. White Paper, supra note 256, § 3.1.3.

[FN297]. Ln Sisulu, Minister, S. Afr. Dep't of Hous., Keynote Address at City Development World Africa 2006 (Nov. 7 , 2006) (transcript available at http://www.info.gov.za/speeches/2006/06111711151001.htm).

[FN298]. Minister Tokyo Sexwale, Speech at the Human Settlements Social Contract Plenary Session in Boksburg (Nov. 26, 2009), available at http:// www.housing.gov.za/Content/Media\%20Desk/Speeches/2009/26\%20November\%202009.htm.

[FN299]. Life: My Mother Built This House, supra note 289. The government's N2 Gateway Project was created to address the informal settlements along the N2 highway on the outskirts of Cape Town at sites from District Six to Joe Slovo, Netreg, New Rest and Boys Town to Delft. For more information and statistics about this ambitious project, see S. Afr. Yearbook, 2009/2010, supra note 279, at 312.

[FN300]. S. Afr. Const. 1996. ch. II, § 26(1).

[FN301]. Andrews, From Gender Apartheid to Non-Sexism, supra note 120, at 720.

[FN302]. Lockett, supra note 10, at 20-21.

[FN303]. Id. at 21.

[FN304]. Kim, supra note 151, at 6 (paraphrasing Felicity Kaganas \& Christina Murray, Law and Women's Rights in South Africa: An Overview, in Gender and the New South African Legal Order 37, 37 (Christina Murray ed., 1994)).

[FN305]. Life: My Mother Built This House, supra note 289. See Press Release, White House Office of the Press Sec'y, Fact Sheet on Victoria Mxenge Housing Savings (Mar. 26, 1998) (summarizing the Housing Savings Scheme). While this Article focuses on the members of the Victoria Mxenge savings plan, this group has received generous and effective assistance from two non-governmental organizations: People's Dialogue and The Homeless People's Federation. Id. The People's Dialogue has since ceased operations. People's Dialogue Homepage, http://www.dialogue.org.za/ (last visited Nov. 7, 2010).

[FN306]. Life: My Mother Built This House, supra note 289.

[FN307]. Maria Allison, Environmental Health and Sanitation Explored Through a Framework of Governance: A Case Study of Informal Settlements in South Africa, 13 Urb. F. 169, 170 (2002) (quoting Maxine Reitzes, Panel 3: How should civil society formations relate to structures of representative government?, in Civil Society After Apartheid: Proceedings of a Conference Convened by the Centre for Policy Studies on the Role and Status of Civil Society in Postapartheid South Africa 99, 101 (Richard Humphries \& Maxine Reitzes eds., 1995)). 
[FN308]. Id.

[FN309]. See id.

[FN310]. See generally Scott Bollens, Community Development in Democratic South Africa, 35 Community Dev. J. 167 (2000) (discussing the potential roles for civil society organizations in post-apartheid South Africa).

[FN311]. Allison, supra note 307, at 170 (quoting Heather Ferguson-Brown, Social Development in a Developing Democracy, 31 Community Dev. J. 187, 187 (1996)).

[FN312]. See Life: My Mother Built This House, supra note 289; see also Secretary of State Hillary Rodham Clinton, Remarks During Visit to Victoria Mxenge Housing Development (Aug. 8, 2009), available at http:// www.state.gov/secretary/rm/2009a/08/127011.htm.

[FN313]. Id. See also Annie Barbara H. Chikwanha, The Politics of Housing Delivery: A Comparative Study of Administrative Behaviour in South Africa and Zimbabwe 202 (June 2005) (unpublished Ph.D. thesis, University of Bergen, Norway), available at https://bora.uib.no/bitstream/1956/1141/1/thesis\%20dec\% 202005.pdf.

[FN314]. Id.; cf. Andrews, From Gender Apartheid to Non-Sexism, supra note 120, at 720.

[FN315]. Geoff Budlender, Op-Ed., Great Gaps in Land and Housing, Fin. Mail, July 13, 2001, at 19.

[FN316]. There are some very interesting studies on generational differences in the housing preferences of women in the Cape Town area. See, e.g., Lee, supra note 132, at 615 (adopting a trans-generational approach to understanding women's involvement in the process of settling Cape Town).

[FN317]. See Life: My Mother Built This House, supra note 289.

[FN318]. Patricia A. Wilson \& Christina Lowery, Building Deep Democracy: The Story of a Grassroots Learning Organization in South Africa, 9 Plan. F. 47, 56 (2003).

[FN319]. See Life: My Mother Built This House, supra note 289.

[FN320]. See id.

[FN321]. See id.

[FN322]. Id.

[FN323]. See Alan Gilbert, Financing Self-help Housing: Evidence from Bogotá, Colombia, 5 Int'l Plan. Stud. 165, $166-67$ (2000).

[FN324]. See id. at 167.

[FN325]. E.g., id.

[FN326]. E.g., id. at 168.

[FN327]. Cf. Robin Palmer, Lawyers and Land Reform in South Africa: A Review of the Land, Housing \& Development Work of the Legal Resources Centre 7-8 (2001), available at http://www.lrc.org.za/Docs/Papers/palmer.pdf. 
[FN328]. Victoria Mxenge became a political activist following the murder of her husband, Griffiths Mxenge, in 1981. A prominent member of the United Democratic Front ("UDF") and of the Natal Organisation of Women, she was part of the legal defense team for the UDF and Natal Indian Congress during the Pietermaritzburg Treason Trial. She was assassinated, before the trial, in 1985. See Victoria Mxenge, S. Afr. Hist. Online, http:// www.sahistory.org.za/pages/people/bios/mxenge-v.htm (last visited Sept. 22, 2010).

[FN329]. Story of the Urban Poor, The Hindu, Apr. 8, 2001, available at http://www.hinduonnet.com/2001/04/08/stories/13080612.htm. Mahila Milan translates to "women together" in Hindi, and it is a "network of collectives of women who come together to share experiences and to save." Diana Mitlin, Learning from the Experts: A New Approach to Poverty Reduction, 1 Critical Soc. Work 1, 1 (2000), available at http:// www.uwindsor.ca/criticalsocialwork/learning-from-the-experts-a-new-approach-to-poverty-reduction-south-african-hom eless-peoples-federat.

[FN330]. Story of the Urban Poor, supra note 329.

[FN331]. See Life: My Mother Built This House, supra note 289.

[FN332]. Cf. Lee, supra note 132, at 625. The use of this informal financing option was practical because, as previously discussed, access to formal financial lenders was not available to the many Victoria Mxenge members who did not have verifiable formal employment or credit histories. Further, mortgage lenders were not able to offer loans directly to African leaseholders until the mid-1980s for home construction and improvement. Id. However, experts suggest that the use of umgalelo-style schemes may have been an attractive option even had formal bank funding been a possibility because it allowed the participants of the umgalelo greater autonomy in deciding how funds could be used. Id.

[FN333]. Wilson \& Lowery, supra note 318, at 58.

[FN334]. See id.

[FN335]. United Nations Dev. Programme-S. Afr., Profile: Patricia Matolengwe of the Victoria Mxenge Housing Savings Scheme (on file with author).

[FN336]. Wilson \& Lowery, supra note 318, at 57.

[FN337]. Life: My Mother Built This House, supra note 289. See also Press Release, White House Office of the Press Sec'y, supra note 305. According to the William J. Clinton Foundation website, USAID provided a $\$ 300,000$ two-year grant in 1998 to two South African organizations for technical assistance to the Victoria Mxenge project. Id. USAID also provided \$3,000,000 in grants to South Africa's Ministry of Housing and Infrastructure Development. Id.

[FN338]. In many of the savings schemes comparable to that organized by the Association, "loans [were] granted on the basis of active and long-term engagement in saving groups rather than the actual accumulation of funds." Millstein et al., supra note 275, at 463. See also The Goedgedacht Forum for Social Reflection, A Dialogue on Sustainable Development - Inspired by the Study Sustainable Germany - A Contribution to Global Sustainable Development (Dec. 1997) (on file with author) [hereinafter The Goedgedacht Forum for Social Reflection]. Reports indicate that, in similar projects, interest charges are only one percent (1\%) per month, a rate set to cover inflation and to recover administration costs. Baumann \& Mitlin, supra note 276, at 34. Some projects have required a deposit of five percent (5\%), with maximum loans of 10,000 ZAR (about 1,421 USD) and monthly payments averaging 120 ZAR (approximately 17 USD). Id.

[FN339]. See, e.g., Salma Ismail, An Evaluation of the Victoria Mxenge Housing Development Association from a 
Gender Perspective, in Breaking Through: Engendering Monitoring and Evaluation in Adult Education 88, 93 (Carolyn Medel-Anonuevo, ed. 1999), available at http://www.eric.ed.gov/PDFS/ED473600.pdf.

[FN340]. Millstein et al., supra note 275, at 463 (citations and emphasis omitted). Some trace the intellectual origin of this type of collective action to John Dewey's "pragmatist philosophy of learning from action for the betterment of all [and] organizational development, which focuses on the transformational nature of participation in groups." Wilson \& Lowery, supra note 318 , at 50. However, identifying a non-indigenous source is unnecessary. As these same authors note, there are other attributable factors, such as "literature on women's ways of knowing, indigenous ways of knowing and decision making, and education for participation." Id. at 51. One need not look beyond the historical chronicles of women's actions in South Africa to find a record of success via collective action and solidarity. This record is consistent with many of the formulations of African feminism, those that posit an inclusive ideology with a focus on familial and communal caring. See, e.g., supra text accompanying notes 31-62.

[FN341]. See Chikwanha, supra note 313, at 198. Tales abound of the difficulty in identifying the owners of, and of gaining access to, suitable plots of land in South Africa, a legacy of apartheid South Africa in which there existed "a complex system of ownership" and a "fragmented" administrative responsibility for state lands. See, e.g., Millstein et al., supra note 275 , at 466 .

[FN342]. Allison, supra note 307, at 177; Chikwanha, supra note 313, at 198; Story of the Urban Poor, supra note 329.

[FN343]. See Victoria Mxenge, Everything2.com, http:// everything2.com/e2node/Victoria\%2520Mxenge (last visited Apr. 30, 2006). Either consciously or subconsciously, Association members were carrying on rural traditions in which the participation of women in the construction of homes was common and expected. Lee, supra note 132, at 617. Moreover, "as female-headed households became a more central feature of township landscapes in the latter decades of apartheid, elderly women in particular became important initiators, investors and designers in the [construction] process." Id.

[FN344]. See Wilson \& Lowery, supra note 318.

[FN345]. Life: My Mother Built This House, supra note 289.

[FN346]. Cf. Wilson \& Lowery, supra note 318, at 59 ("Guided by other groups who had already designed and built houses, Charlotte's group went on to construct cardboard model houses and draw their house plans.”).

[FN347]. The South African Homeless People's Federation NGO provided invaluable technical guidance to the group. See The Goedgedacht Forum for Social Reflection, supra note 338.

[FN348]. See id., supra note 338.

[FN349]. Lee, supra note 132, at 623, 626.

[FN350]. Id. The government has recognized problems with the construction industry. "Regarding the construction industry, including wholesale and retail suppliers, it is important for these service providers if we are to remain partners to reconsider the exorbitant prices of their materials, something which has a severe impact on housing costs.... As we speak, there is total of 40000 houses countrywide, that must be rectified or completely demolished as a consequence of bad workmanship. Sadly, two such houses have killed a woman and a 13-year-old child. Clearly, somebody must account." Speech by Minister Tokyo Sexwale to the Human Settlements Social Contract Plenary Session, supra note 298. The government established the National Home Builders Registration Council through the Housing Consumer Protection Meas- 
ures Act 95 of 1998 to maintain construction quality standards in the home building industry and to protect housing consumers from defective materials and/or construction methods. See National Home Builders Registration Council, BondCredit.co.za, http:// www.bondcredit.co.za/building-a-home/national-home-builders-registration-council.php (last visited Nov. 4, 2010). See also text accompanying note 405.

[FN351]. See, e.g., Wilson \& Lowery, supra note 318, at 59. See also SDI, Report 4, Face to Face - A Comprehensive Detailed Discussion of the Ideas, Practices, and Results of Horizontal or Community - to - Community Exchanges Within the SDI Network, available at http://sdinet.org/reports/r4.htm (last visited Sept. 22, 2010).

[FN352]. See SDI, Report 4, Face to Face - A Comprehensive Detailed Discussion of the Ideas, Practices, and Results of Horizontal or Community - to - Community Exchanges Within the SDI Network, available at http:// sdinet.org/reports/r4.htm (last visited Sept. 22, 2010)..

[FN353]. Life: My Mother Built This House, supra note 289.

[FN354]. These numbers convert to approximately 54, 65, and 72 square meters. See A Dialogue on Sustainable Development, supra note 338. According to residents, their homes are substantially larger than government-built houses. See Story of the Urban Poor, supra note 329. Observers indicate that "the majority of people are unhappy with the houses built by the Government, which are too small for their large families. Those who accepted these houses are dissatisfied. As a result, many have sold out and moved back to their villages." Id. The 2009/20010 South Africa Yearbook notes that government-provided homes are only now being built "of a larger size and better quality, with more houses of 40 to 45 square metres (430 square feet) being constructed." See S. Afr. Yearbook, 2009/2010, supra note 279, at 308.

[FN355]. Story of the Urban Poor, supra note 329.

[FN356]. Allison, supra note 307, at 177.

[FN357]. E.g., Press Release, White House Office of the Press Sec'y, supra note 305.

[FN358]. Life: My Mother Built This House, supra note 289

[FN359]. Id. "Victoria Mxenge was built on land that was owned by the Catholic Church and acquired after prolonged negotiations with church and local state representatives; Hazeldean was constructed on land that was purchased from a private land owner, and Vukuzenzele [was] developed on land that was taken over after a collective land occupation and subsequent negotiations with the registered land owner." Millstein et al., supra note 275, at 465-66.

[FN360]. Life: My Mother Built This House, supra note 289.

[FN361]. Id. ("Not only has [the saving scheme] enabled each of them to take out loans to build the kind of houses they want, it's also meant that the money repaid goes back into their own community. The crèche provides child-care for working mothers. The women have started a small pottery. With a scheme to grow lilies for the commercial market, income is generated for the women who participate.").

[FN362]. E.g., Profile: Patricia Matolengwe, supra note 335; Story of the Urban Poor, supra note 329.

[FN363]. Story of the Urban Poor, supra note 329.

[FN364]. See A Dialogue on Sustainable Development, supra note 338. 
[FN365]. Life: My Mother Built This House, supra note 289. "Urban greening initiatives [to] promote self-sufficiency and income-generation through urban-based agriculture [and horticulture] have been a prominent feature of recent township development [in South Africa]. Lee, supra note 132, at 621 n.45. Communities similar to Victoria Mxenge also have begun to explore commercial activities, conference and development training facilities, and commercial centers. See Baumann \& Mitlin, supra note 276, at 34.

[FN366]. The Victoria Mxenge development has attracted international media attention, donors, and visiting dignitaries, including former President Bill Clinton and Secretary of State Hillary Clinton, high-level South African government officials, and EU delegations. See Steven Robins, Grounding 'Globalization from Below': 'Global Citizens' in Local Spaces, in What holds us together: Social Cohesion in South Africa 242, 263 (2003). Secretary Clinton has visited the Victoria Mxenge community several times, even laying bricks there with President Clinton and their daughter Chelsea, and has visited there as recently as August 2009. See Secretary of State Hillary Rodham Clinton, Remarks During Visit to Victoria Mxenge Housing Development, supra note 312; see also Alex Duval Smith, Hillary Clinton Ends Successful South Africa Visit at Housing Project, The Observer (Aug. 9. 2009), available at http:// www.guardian.co.uk/world/2009/aug/09/hillary-clinton-south-africa-housing. Visitors to Cape Town can visit the Victoria Mxenge community, meet its residents and discover more about its success as part of a Cape Care Route tour. This tour is part of Cape Town's responsible and sustainable tourism campaign to empower local communities and promote the environment. See Cape Care Route, Open Africa, http://www.openafrica.org/route/cape-care-route (last visited Sept. $22,2010)$.

[FN367]. See Mitlin, supra note 329, at 1.

[FN368]. In December 1997, the group had 286 members, 280 of whom were women. The Goedgedacht Forum for Social Reflection, supra note 338. See also Press Release, White House Office of the Press Sec'y, supra note 305. This author has been unable to locate more recent membership data.

[FN369]. As previously mentioned, this article focuses on the members of the Victoria Mxenge Housing and Development Association. However, the Association has received generous and effective assistance from two non-governmental organizations, People's Dialogue and The Homeless People's Federation, as well as from other funding agencies. Press Release, White House Office of the Press Sec'y, supra note 305.

[FN370]. See, e.g., Gilbert, supra note 323, at 168 (noting how Peruvian economist Hernando de Soto predicted comparable results in 1989 relating to provisional titling programs). See generally Hernando de Soto, The Other Path: The Economic Answer to Terrorism (1989); Hernando de Soto, The Mystery of Capital: Why Capitalism Triumphs in the West and Fails Everywhere Else (2000) (discussing the hidden architecture of property rights and their impact upon the creation of capital).

[FN371]. The South African government has recognized the importance of such capacity building. See Human Settlements, S. Afr. Gov't Info., http:// www.info.gov.za/aboutsa/housing.htm\#capacity (last updated Jul. 5, 2010). Recent reforms attempt to strengthen both institutional, administrative, community, and consumer capacity. See S. Afr. Yearbook, 2009/2010, supra note 279, at 312; National Housing Code, supra note 267, at pt. 2, Section 4.3.5, at 29 (follow "National Housing Code, 2009" hyperlink to the "Simplified Guide and Policy Context" link; then follow the "Policy Context" link.) This includes the provision of capacity building grants. National Housing Code, supra note 267, at pt. 1, Section 5.3, at 24 (follow "National Housing Code, 2009" hyperlink to the "Simplified Guide and Policy Context" link; then follow the "Simplified Guide" link.)

[FN372]. Activists and NGOs have found the self-survey skills to be an effective tool for accessing state resources: 
"Self-enumeration and information gathering are ... seen as crucial for engaging the state on more equal terms and holding it accountable to its citizens. These practices reflect a sophisticated understanding of the political and bureaucratic machinations of the modern state. By appropriating these rituals of bureaucratic state power, the federations acquire leverage in their negotiations with the state to secure resources such as housing and health."

Robins, supra note 366, at 259.

[FN373]. Id. at 254.

[FN374]. Allison, supra note 307, at 183. Author Allison utilizes Gill Walt's classification system for defining interest groups. Walt posits that insider groups are those that are consulted by government and play a role in policy formation; outsider groups have no legitimacy with government and have difficulty in influencing the policy process; and threshold groups may sometimes be accepted as insider groups, but often are perceived as outsiders. Id. at 173 (describing the work of Gill Walt, Health Policy: An Introduction to Process and Power (1994)).

[FN375]. Allison, supra note 307, at 173. This transition from "outsider" to "threshold" group correlates to the transformation of most South African civil society organizations during the country's democratic transition. This transition radically

transformed the system of formal and informal political channels that are available to popular movements. Civics were, prior to 1994, generally opposed to the apartheid state and operated with a high degree of political autonomy vis-à-vis state institutions and government.... [T] his pattern does not fundamentally alter the understanding of state/civics relations as principally antagonistic prior to the democratic transition. Post-apartheid political opportunity structures are clearly of a very different nature.... [T] he political transition has been an ambiguous political process for popular movements--producing new and widened political spaces but also tendencies towards de-politicisation.

Millstein et al., supra note 275, at 462 (emphasis omitted). It has been a challenge for apartheid resistance groups to realign into grassroots movements for advocating women's or community rights. After the democratic elections in 1994, many of the resistance groups became stakeholders in governmental processes, as service providers, contractors, or advisors. While this increased their access to formal state institutional structures, it often weakened their ties to their communities. Wilson \& Lowery, supra note 318 , at 49.

[FN376]. Robins, supra note 366, at 244 (citing Robert Putnam, Making Democracy Work: Civic Traditions in Modern Italy (1993)). Robins further notes that "Putnam's work has generated an enormous World Bank-sponsored research industry addressing the role of trust and social capital in creating the conditions for 'good governance' and democracy." Id. (citing such researchers as Valerie Braithwaite, Margaret Levi, and Adam Seligman). "Trust, networks and norms are also seen as the crucial ingredients for the creation of social capital and the maintenance of cooperative economic relationships." Id. With regard to what some have labeled the thickening of social capital, Robins also references Deborah Bryceson, who writes that the notion of social capital

is believed to generate improved civic leadership, better information flows within and between networks, and more democratic interaction and efficient local economies. Thus, investment in social capital within the rural community is seen as a way of individual actors improving their access to resources at the same time as they are paving the way for a 'sustainable' 'enabling environment' for their communities.

Deborah Fahy Bryceson, Sub-Saharan Africa Betwixt and Between: Rural Livelihood Practices and Policies 42 (African Studies Center, Working Paper No. 43, 1999), available at https://openaccess.leidenuniv.nl/dspace/handle/1887/12912. According to Robins, this perspective is reminiscent of “'Adam Smith's 'invisible hand', metaphorically wearing a social rather than an economic glove." Robins, supra note 366, at 301 (quoting Deborah Bryceson, African Rural Labour, Income Diversification and Livelihood Approaches: A Long-term Development Perspective, 26 Rev. Afr. Pol. Econ. 316 (1999) (emphasis omitted)). 
[FN377]. The South African Homeless People's Federation is a network of organizations that provided support to communities establishing savings and loan schemes, mapping and planning neighborhoods, and designing and developing pilot housing and toilet facilities. See Mitlin, supra note 329. The group also worked with municipal and provincial governments and with the national government of South Africa to access and acquire land and to claim housing subsidies for slum and shack dwellers in their communities. See Baumann \& Mitlin, supra note 276, at 32-34. The Federation's revolving Utshani Fund, capitalized by both grants and loan funds from foreign donors, international development agencies, and a government grant, provided bridge loans to its members, all of whom were "too poor to be deemed good risks by financial institutions." Wilson \& Lowery, supra note 318, at 54. See also Baumann \& Mitlin, supra note 276, at 34. Further, members who received a subsidy through the Federation contributed two percent (2\%) of their subsidies back to the Fund. Baumann \& Mitlin, supra note 276, at 34. The concept was that the bridge loans would give members access to the resources they needed to build their homes or to secure "top up" funds, resources which would later be retired by government subsidy funds. Id. at 33. However, the subsidy funds did not always materialize in a timely fashion or at all, and the Fund found itself in an "increasingly tenuous situation as the "de facto creditor to a large group of very poor South Africans who could not be expected to repay large housing loans and who did not believe that this was what they had agreed to do."” Wilson \& Lowery, supra note 318, at 54.

[FN378]. Profile: Patricia Matolengwe, supra note 335. See also Press Release, White House Office of the Press Sec'y, supra note 305 .

[FN379]. See Profile: Patricia Matolengwe, supra note 335.

[FN380]. See The Goedgedacht Forum for Social Reflection, supra note 338.

[FN381]. Id., supra note 338.

[FN382]. Story of the Urban Poor, supra note 329.

[FN383]. See, e.g., Glen Robbins et al., Study on "Employment Aspects of Slum Upgrading" Practices and Opportunities Identified in Two South African Case Studies (2005), available at http:// www.oit.org/public/english/employment/recon/eiip/download/workshop/robbins.pdf. Housing reforms also embrace this model of local economic development, explicitly identifying job creation as a goal of government-sponsored housing programs. National Housing Code, supra note 267, Part 2, Section 4.3.7, at 32 (follow "National Housing Code, 2009" hyperlink to the "Simplified Guide and Policy Context" link; then follow the "Policy Context" link.) "Local economic development is promoted with money spent being kept in the community increasing the local multiplier effect[.]" Id. Part 3, Section 2(f), at 9 (follow "National Housing Code, 2009" hyperlink to the "Incremental Interventions" link; then follow the "Enhanced People's Housing Process" link.).

[FN384]. See Press Release, White House Office of the Press Sec'y, supra note 305. Such horizontal learning exchanges are taking place between both informal networks and more formal federations of grassroots organizations across the globe, networks in which the Victoria Mxenge women are involved. Mitlin, supra note 329. For example, it is estimated that, in 1999, the network of international members involved in Shack/Slum Dwellers International ("SDI") numbered over 4,000,000 individuals from twelve countries. See id. Organizations in each of these countries are comprised of small autonomous women-centered and -managed groups, and their combined savings total millions of dollars. Id.

[FN385]. Cf. Wilson \& Lowery, supra note 318, at 54.

[FN386]. See, e.g., Gilbert, supra note 323, at 180. 
[FN387]. Cf. id. at 180-182.

[FN388]. Marie Huchzermeyer, A Legacy of Control? The Capital Subsidy for Housing, and Informal Settlement Intervention in South Africa, 27 Int'l J. Urb. \& Regional Res. 591, 591 (2003) [hereinafter Huchzermeyer, A Legacy of Control].

[FN389]. Id.

[FN390]. See id.

[FN391]. See id. at 595.

[FN392]. Baumann \& Mitlin, supra note 276, at 32.

[FN393]. The government has taken steps to provide larger dwellings. The 2009 Housing Code specifies that each house to be constructed through governmental programs must have a floor area of at least 40 square meters (approximately 430 square feet), with two bedrooms; a separate bathroom with a toilet, a shower, and a hand basin; a combined living area and kitchen with wash basin; electrical installations; and environmentally efficient designs. National Housing Code, supra note 267, Part 1, Part C, Section 2.7, at 54 (follow "National Housing Code, 2009" hyperlink to the "Simplified Guide and Policy Context" link; then follow the "Simplified Policy" link.) Compare this to the structures as small as 130 square feet that some previous subsidy recipients received. Baumann \& Mitlin, supra note 276, at 38.

[FN394]. See Robins, supra note 366, at 258.

[FN395]. Id.

[FN396]. Cf. Mitlin, supra note 329.

[FN397]. Id.

[FN398]. See Story of the Urban Poor, supra note 329.

[FN399]. Baumann \& Mitlin, supra note 276, at 35. Sources indicate that this increased value may be as much as three to eight times the cost of the building material and labor, such figures having been offered by potential purchasers. Id. House values conservatively have been estimated at 30,000-50,000 ZAR. Id. at 36. This value contrasts dramatically with the values of the housing in many developer-driven housing developments. Id. at 35. In many of these non-self-build developments, beneficiaries have resold their new houses for far less than the amount spent on them by the state. Id. These values do not reflect the potential health and various intangible benefits to Victoria Mxenge community members that accrue from higher quality construction, including, among other possible benefits: (1) reduced dampness and risk of fires and flooding associated with living in concrete housing; (2) improved work and school attendance and productivity, not to mention reduced health care spending associated with better health; (3) increased qualities such as pride and confidence derived from home ownership; and (4) increased social cohesion, reduced crime, and reduced social anomie. See generally Allison, supra note 307.

[FN400]. Life: My Mother Built This House, supra note 289. See also supra note 350 (discussing the government' recognition of problems with construction quality and its efforts to address them).

[FN401]. See Millstein et al., supra note 275, at 461. 
[FN402]. Huchzermeyer, supra note 277, at 307.

[FN403]. See Millstein et al., supra note 275, at 461 ("One of the main achievements of the SAHPF ... has been a discursive shift away from top-down technocratic development management to a participatory people-centred housing process.”).

[FN404]. One commentator has noted that the "time-consuming burden of their 'triple role' (as breadwinners, care[givers] and active community 'managers') ... can be a serious impediment to women's participation in such projects." Lee, supra note 132 , at 626.

[FN405]. Housing Consumers Protection Measures Act 95 of 1998.

[FN406]. Lee, supra note 132, at 626.

[FN407]. Housing Consumers Protection Measures Act 95 of $1998 \S 3$.

[FN408]. Id. §18.

[FN409]. National Housing Code, supra note 267, pt. 3, vol. 4 (follow "National Housing Code, 2009" hyperlink to the "Incremental Interventions" link; then follow the "Enhanced People's Housing Process" link.). While a thorough analysis of the People's Housing Process exceeds the scope of this article, it should be noted that one critique expressed by some is that

the implementation of the [People's Housing Process] remains within the neo-liberal frame with an emphasis on delivery of houses, participation as consultation and a continued neglect of the importance of building community capacity.... [Critics] argue that systematically uneven power relations between marginalised communities and their state, nongovernmental and private partners in the housing process remain unaltered.

Millstein et al., supra note 275, at 465 (citations omitted). The 2009 revisions to the Housing Code attempt to respond to this failing, stating that the new EPHP "is a government housing-delivery mechanism that ... focus[es] on the outcomes of the housing process as a whole rather than just how the housing product is delivered .... The EPHP provides for a process in which beneficiaries actively participate in decision-making ... and ... are empowered individually and collectively so that the community ultimately takes control of the housing process themselves. This includes identifying the land, planning the settlement, getting approvals and resources to begin the development, contracting out or building the houses and providing the services, living in and upgrading their homes and continually improving the community[.]" National Housing Code, supra note 267, pt. 3, vol. 4, § 2, at 9-10 (follow "National Housing Code, 2009” hyperlink to the "Incremental Interventions" link; then follow the "Enhanced People's Housing Process" link).

[FN410]. Allison, supra note 307, at 182 (quoting S. Afr. Ministry of Hous., Housing the Nation: Doing Justice to Delivery (1997)).

[FN411]. See Millstein et al., supra note 275, at 465.

[FN412]. See S. Afr. Yearbook, 2009/2010, supra note 279, at 315.

[FN413]. Women's Build, Dep't Human Settlements, Republic S. Afr., http:// www.dhs.gov.za/Content/Stakeholder\%20Management/women/index_Women.htm (last visited Nov. 10, 2010). For more information of the 1956 Women's March, see supra note 156 and accompanying text.

[FN414]. Women's Build, Dep't Human Settlements, Republic S. Afr., http:// 
www.dhs.gov.za/Content/Stakeholder\%20Management/women/index_Women.htm (last visited Nov. 10, 2010).

[FN415]. National Housing Code, supra note 267, Vol. 4, Section 3, at 13-14 (follow "National Housing Code, 2009" hyperlink to the "Incremental Interventions" link; then follow the "Enhanced People's Housing Process" link.).

[FN416]. Life: My Mother Built This House, supra note 289.

[FN417]. Id. See also, e.g., National Housing Code, supra note 267, Vol. 4, Section 3.10, at 14; Section 7.3.4, at 31 (follow "National Housing Code, 2009" hyperlink to the "Incremental Interventions" link; then follow the "Enhanced People's Housing Process" link.).

[FN418]. Id.

[FN419]. See, e.g., Mitlin, supra note 329.

[FN420]. See id.

[FN421]. See, e.g., Gilbert, supra note 323, at 181.

[FN422]. See Baumann \& Mitlin, supra note 276, at 37-38.

[FN423]. See, e.g., Gilbert, supra note 310, at 184.

[FN424]. Story of the Urban Poor, supra note 329.

[FN425]. Id.

[FN426]. Baumann \& Mitlin, supra note 276, at 38. Commentators have noted the somewhat perverse economic effects of these peripherally located housing projects. See, e.g., Huchzermeyer, supra note 277, at 317-18. Transportation costs can place significant strain on the household economies of the very poor and may lead some to abandon their new homes to return to squatting in the urban areas where work is more readily available. E.g. id. These peripheral communities have budgetary impacts on government as well, requiring increased government subsidies for public transport and food subsidy programs and causing loss of revenue due to non-payment for services. See, e.g., id. at 318-19. This can become a downward spiral. If local governments suffer from budgetary constraints, this may result in the deterioration of housing developments caused by inadequate servicing, maintenance, and delays in the provision of social, educational, commercial, and recreational facilities. Cf. id. at 322.

[FN427]. Salma Ismail, A Poor Women's Pedagogy: "When Ideas Move in People's Hands and Hearts, They Change, Adapt, and Create New Solutions,” 31-3/4 Women's Studies Q. 94, 105 (2003).

[FN428]. Id. at 89.

[FN429]. The Goedgedacht Forum for Social Reflection, supra note 338.

[FN430]. Id.

[FN431]. See Mitlin, supra note 329.

[FN432]. See Press Statement, Commission on Gender Equality, Gender Commission Gives Thumbs Up To President on 
Increase of Women Cabinet Ministers (Apr. 29, 2004), available at http://www.cge.org.za/index.php?option=com_docman\&task=doc_details\&gid=85\&Itemid= (last visited Sept. 22, 2010).

[FN433]. See Story of the Urban Poor, supra note 329.

[FN434]. Id.

[FN435]. Id.

[FN436]. Huchzermeyer, supra note 277, at 314.

[FN437]. Id. at 313.

[FN438]. Id.

[FN439]. Id. at 314.

[FN440]. See generally id. See also Huchzermeyer, A Legacy of Control, supra note 388, at 597.

[FN441]. Huchzermeyer, supra note 277, at 314.

[FN442]. Community Reinvestment Act of 1977, 12 U.S.C. $\S \S 2901-08$ (2005). Many have blamed the Community Reinvestment Act for the collapse of the subprime lending market in the U.S. Compare Jerry Bowyer, Don't Blame the Markets, N.Y. Sun, Apr. 18, 2008, at 9 ("The government compels banks to make loans in poor neighborhoods even if the applicants are not considered prime borrowers.") with Aaron Pressman, Community Reinvestment Act Had Nothing to Do with Subprime Crisis, Businessweek Investing Blog, Sept. 29, 2008, http:// www.businessweek.com/investing/insights/blog/archives/2008/09/community_ reinv.html ("Fresh off the false and politicized attack on Fannie Mae and Freddie Mac, today we're hearing the know-nothings blame the subprime crisis on the Community Reinvestment Act--a 30-year-old law that was actually weakened by the Bush administration just as the worst lending wave began. This is even more ridiculous than blaming Freddie and Fannie.”).

[FN443]. Huchzermeyer, supra note 277, at 314. While such legislation has been proposed in South Africa, it has faced strong opposition from banks and the financial services industry. See Woodstock Inst., A Global Survey of Community Reinvestment Laws: The Obligation of the Private Sector to Serve the Underserved in Several Countries 10 (2004). As far as this author can ascertain, no conclusive action has been taken. See Draft Community Reinvestment (Housing) Bill, 2002, Bill 23423 (GA), available at http:// www.info.gov.za/view/DownloadFileAction?id=67059.

[FN444]. See supra text accompanying note 350.

[FN445]. S. Afr. Yearbook, 2009/2010, supra note 279, at 315.

[FN446]. The South African Women in Construction organization is a network of women in the industry. Its website has a very moving poem, one stanza of which reads:

Imagine a woman who authors her own life. A woman who exerts, initiates and moves on her own behalf Who refuses to surrender except to her truest self and to her wisest voice.

See, e.g., South African Women in Construction, http:// www.inoventing.com/sawic/index.html (last visited Nov. 5, 2010).

[FN447]. See Housing Subsidies, Law24.com--South Africa, http:/ 
www.law24.com/understand-your-legal-issue/law-for-the-layman/index.html?domid=/ slucb/9kmdb/ateeb/16mfb/9g1rb (last visited Sept. 22, 2010).

[FN448]. All of the individuals, organizations, developer(s), and governmental units who were involved in a new projectlinked subsidy housing project had to reach agreement, the Social Compact Agreement, about their roles and responsibilities. See id.

[FN449]. See id.

[FN450]. See id.

[FN451]. See Gilbert, supra note 323.

[FN452]. See S. Afr. Yearbook, 2009/2010, supra note 279, at 317-19 (detailing governmental efforts to make housing more accessible to low income South Africans).

[FN453]. Huchzermeyer, supra note 266, at 318. The issue of illegal land invasions is beyond the scope of this article. Should readers be interested in this topic, see id.

[FN454]. See id.

[FN455]. The Housing Development Agency Act, 2008.

[FN456]. Id., § 4.

[FN457]. Housing Development Agency: Progress Report; \& International Agreement Process Briefing (Mar. 3, 2010), available at http:// www.pmg.org.za/report/20100303-housing-development-agency-progress-reportinternational-agreement-pr.

[FN458]. S. Afr. Const. 1996. ch. II, § 25(2).

[FN459]. S. Afr. Const. 1996. ch. II, § 25(4)(a).

[FN460]. The Housing Development Agency Act, 2008, § 6(2).

[FN461]. S. Afr. Const. 1996. ch. II, § 25(3).

[FN462]. S. Afr. Const. 1996. ch. II, § 25(3)(a)-(e).

[FN463]. See supra note 426 and accompanying text.

[FN464]. See Mitlin, supra note 329.

[FN465]. Id.

[FN466]. National Housing Code, supra note 267, pt. 3, at 9-10 (follow "National Housing Code, 2009" hyperlink; then follow "Incremental Interventions" hyperlink; then follow "Enhanced People's Housing Process" hyperlink).

[FN467]. See generally Chikwanha, supra note 313, at 159, 161, 164-65, 168-69, 187 (describing this disconnect in the context of housing). 
[FN468]. Cf. id. at 177 (“[R]esidents who refused to approach the responsible government authority and instead went to a civic group during a land dispute. 'This was because the people trusted the civic to take up their issues effectively. They had no faith in speaking to the white people[.]"').

[FN469]. See Pillay et al., supra note 109, at 3.

[FN470]. Id. at 3-5.

[FN471]. See id. at 17.

[FN472]. See Women's Build, supra note 413.

[FN473]. Arndt, supra note 5, at 34.

[FN474]. See Hillary Rodham Clinton, It Takes a Village: And Other Lessons Children Teach Us (1996).

[FN475]. See Mitlin, supra note 329.

[FN476]. See David Schalkwyk, The Authority of Experience or the Tyranny of Discourse: An Inescapable Impasse?, in South African Feminisms, supra note 5, at 57-58 (arguing against Lockett's position that non-African women could not "engage seriously and openly" with African women's experiences due to their different experiences by evoking a different concept of experience: communal experience).

[FN477]. See Jenny de Reuck, Writing Feminism/Theoretical Inscriptions in South Africa, in South African Feminisms, supra note 5, at 38-39 (M.J. Daymond ed., 1996).

[FN478]. Mikell, supra note 2, at 333, 342.

[FN479]. See Sisi Maqagi, Who Theorizes?, in South African Feminisms, supra note 5, at 27, 29.

[FN480]. The author hopes that her observations regarding feminist theory are clearly understood to be descriptive. The discussion of theoretical perspectives is presented to contextualize the achievements of the Association and its members.

[FN481]. See Daymond, supra note 31, at xxxiv.

[FN482]. See Lee, supra note 132, at 614.

[FN483]. Millstein et al., supra note 275, at 457.

[FN484]. Id.

[FN485]. See Banda, supra note 6, at 19.

[FN486]. Lewis, supra note 38, at 102.

[FN487]. See de Reuck, supra note 477, at 40 (“[T] c change social conditions requires that the site of struggle be extended from the realm of discourse theory to include the specific material conditions out of which are constructed the power relations of a society.").

[FN488]. See Arndt, supra note 5, at 23. 
26 Berkeley J. Gender L. \& Just. 19

26 Berkeley J. Gender L. \& Just. 19

END OF DOCUMENT 